\title{
Do Clawback Adoptions Influence Capital Investments?*
}

\author{
Gary C. Biddle \\ Faculty of Business and Economics, The University of Melbourne \\ Lilian H. Chan ${ }^{\#}$ \\ Jeong Hwan Joo \\ Faculty of Business and Economics, The University of Hong Kong
}

\begin{abstract}
We present evidence that clawback provision adoptions influence capital investment mix via managerial compensation incentives. Specifically, we find for a propensitymatched sample of 931 voluntary clawback adoptions that capital investments shift away from R\&D and toward capital expenditures, and for firms with enabling liquidity toward acquisitions, consistent with clawback effects on earnings-linked compensation. Corroborating evidence confirms that these effects are positively related to performance-based pay, growth opportunities, and invariant to risk-toleration incentives, with firms adopting clawbacks also exhibiting capital over-investment. This evidence is timely given a pending SEC rule that would mandate clawbacks for all firms listing on US exchanges.
\end{abstract}

JEL classification: G18, G30, M41, M48

Keywords: Compensation clawback; Performance-based compensation; Capital investment; Real effects; Capital investment efficiency

Data availability: All data used in the study are available from public sources.

\# Corresponding author

Lilian H. Chan

lchan@business.hku.hk

Tel: 852-3917-4217

School of Business and Management

* We thank Gilles Hilary, Paige Patrick, Bjorn Jorgensen, and workshop participants at the University of Hong Kong and the 2017 AAA Annual meeting for helpful comments. Please contact authors at gbiddle@unimelb.edu.au (Gary Biddle), lchan@business.hku.hk (Lilian Chan), and jeongjoo@hku.hk (Jeong Hwan Joo). 


\section{Introduction}

This study presents evidence that capital investment choices are influenced by voluntary adoptions of clawback provisions that authorize boards of directors to recoup executive compensation based on financial results that are later restated. Restitutive clawbacks were sanctioned by Sarbanes-Oxley Act Section 304 (SOX 304, U.S. House of Representatives, 2002) in response to allegations in the early 2000s that executive compensation was boosted by financial misreporting. Despite lax enforcement by the U.S. Securities and Exchange Commission (SEC), U.S. listed firms voluntarily adopting clawback clauses rose from 19 in 2005 to 1,032 in 2012. Similar allegations arising during the 2008-2009 financial crisis motivated Dodd-Frank Act Section 954 (U.S. House of Representatives, 2010) to bar U.S. exchange listings by companies lacking clawback policies. A pending SEC rule to implement DFA $954^{1}$ observes that "while these incentives could result in high-quality financial reporting that would benefit investors, they may also alter operating decisions of executive officers." It also requests "comment on any effect the proposed requirements may have on efficiency, competition and capital formation (SEC 2015, 103-104)."

Consistent with their purported benefits, prior research finds clawbacks to enhance financial reporting quality as evidenced by fewer restatements, larger earnings response coefficients, fewer reported internal control weaknesses, lower audit fees, quicker audit reporting, lower borrowing costs, reduced loan collateral, longer loan terms, positive stock price reactions, and higher sensitivity of chief executive officer (CEO) annual pay to reported earnings

\footnotetext{
${ }^{1}$ Proposed SEC Rule 10D-1 authorizes recovery of excess incentive-based pay received by executive officers without regard to fault in the three fiscal years preceding the date a listed company is required to prepare an accounting restatement, where per Section 16 of the Exchange Act, executive officers include the company's president, principal financial officer, principal accounting officer, any vice-president in charge of a principal business unit, division or function, and any other person who performs policymaking functions for the company (Ackerman 2015; SEC 2015). It is estimated that Rule 10D-1 would apply to 4,845 registrants (SEC 2015, 108).
} 
(Babenko, Bennette, Bizak, and Coles 2015; Chan, Chen, Chen, and Yu 2012; Chan, Chen, and Chen 2013; Chen, Green, and Owers 2014; Dehaan, Hodge, and Shevlin 2013; Iskandar-Datta and Jia 2013). ${ }^{2}$ Related findings indicate that enhanced financial reporting quality increases capital investment efficiency, suggesting a substantive potential clawback benefit (e.g., Biddle and Hilary 2006; Biddle, Hilary, and Verdi 2009; McNichols and Stubben 2008), yet no direct evidence exists. Pertinently, Chan, Chen, Chen, and Yu (2015) report that clawback adoptions induce managers to engage in real transactions manipulation (e.g., cutting research and development expenses) to preserve expected compensation. ${ }^{3}$ Because $R \& D$ expenses are synonymous with $R \& D$ investments (hereafter $R \& D$ ), these findings raise questions of how clawbacks affect capital investment mix choices and how they affect capital investment efficiency.

Prior analytical research suggests possible relations among clawback adoptions, performance-based compensation, earnings management, and capital investment choices. Benmelech, Kandel, and Veronesi (2010) show for a setting in which executives possess private information regarding investment opportunities, boards and market participants rely on earnings to evaluate them, and executives receive stock-based compensation (including annual equity grants, changes in the value of equity holdings, stock-price-linked dismissal), there arise incentives to manage earnings. In particular, executives of firms with high growth opportunities have incentives to exploit growth options and if growth slows, to manage earnings and even forego R\&D projects to maintain a pretence of high earnings growth. Kedia and Philippon (2009) show that executives with stock-based compensation not only manage earnings but also

\footnotetext{
${ }^{2}$ Similar to Dehann et al. (2013), we refer to financial reporting quality as the degree of diligent and unbiased application of financial reporting standards.

${ }^{3}$ In a similar vein, Kyung, Lee, and Marquardt (2016) report that clawback adopters increase non-GAAP earnings management following clawback adoptions.
} 
hire and invest to mask a decline in investment opportunities. By mitigating incentives to boost pay using overstated earnings that might later be restated (Chen et al. 2014; Benmelech et al. 2010), clawback provision adoptions provide executives with incentives to rely more on other means to preserve expected compensation (Ewert and Wagenhofer 2005; Chan et al. 2015). Recent evidence by Chan et al. (2015) that firms adopting clawback provisions reduce R\&D expenses and thus expenditures, while consistent with incentives to preserve earning-linked compensation, begs whether executives thereby lower total capital investment and longer-term value, or rather shift capital investment mix so as to better preserve longer-run profitability and firm value.

By this reasoning, we posit that managers respond to clawback provision adoptions by shifting their capital investment mix away from $\mathrm{R} \& \mathrm{D}$ as previously found, and toward property, plant, and equipment (hereafter capex) and also acquisitions conditional on enabling liquidity, with the effects of clawback adoptions on total capital investment an open empirical question. Our reasoning reflects that $R \& D$ investments reduce earnings immediately with generally delayed and less certain paybacks (Bhagat and Welch 1995; Kothari, Laguerre, and Leone 2002; Coles, Daniel, and Naveen 2006). By comparison, capex expenditures generate formulaic amortization and depreciation charges and nearer-term profits from generally extant business contexts. While acquisition investments can immediately enhance and may never reduce earnings, they also require enabling liquidity, integration with existing operations, and can often require lead-times to execute. The increased proportion of performance-based pay associated with clawback adoptions documented in prior studies is consistent with both enhanced precision in earnings measurement and earnings and risk offsets for managers and provides added incentive to shift investment mix. 
We test these propositions using a propensity-matched sample of 4,200 firm-years for 463 voluntary clawback adoptions between 2005 and 2012 inclusive. ${ }^{4}$ Our findings are consistent with clawback adoptions inducing capital investment mix shifts from R\&D to capex expenditures, and to acquisition expenditures for firms with enabling liquidity. Increased capital expenditures by clawback adopters are positively associated with the likelihood of overinvestment in property, plant, and equipment beyond a level supported by investment opportunities, consistent with an induced investment shift. Corroborative sub-sample tests confirm significant reductions in R\&D investments and significant increases in capital expenditures for firms with higher proportions of performance-based pay, and for firms with higher market-perceived growth opportunities, thus lending support to the effects of clawback adoptions operating via compensation incentives. A sub-sample test also confirms that clawback adoptions are positively associated with the likelihood of overinvestment in property, plant, and equipment and in total capital assets for firms with higher proportions of performance-based pay. The shift in capital investment mix and capital overinvestment remain identical after controlling for the risk-toleration incentives related to executive equity portfolio, indicating that the ex post settling up mechanism introduced by clawback adoptions has a significant incremental effect on capital investment mix.

Our findings contribute to prior research in several ways. First, we extend prior evidence regarding the effects of clawback adoptions to reveal that the $R \& D$ reductions documented in Chan et al. (2015) comprise part of a broader capital investment mix shift away from R\&D and toward capex and acquisitions investments conditional on enabling liquidity. Second, we show

\footnotetext{
${ }^{4}$ The period 2005-2012 provides a sample of voluntary clawback adoptions implemented subsequent to SOX 304 and prior to Dodd-Frank Act provisions that progressively intimated mandatory clawbacks, including Sections 951 (executive compensation adopted on January 25, 2011), 952 (compensation consultants adopted on June 20, 2012), 953 (executive-employee pay ratios adopted on September 18, 2013 and pay-for-performance adopted on April 29, 2015), and 955 (hedging adopted on February 9, 2015), with 954 (clawbacks) pending.
} 
that this shift in capital investment mix results in overinvestment in capital assets. Combined, these findings suggest an unintended consequence of clawback provisions that can help inform a pending proposal for clawback provisions to be a listing pre-condition for U.S. exchanges. Third, our findings contribute insights regarding the relation between financial reporting quality and capital investment efficiency. Whereas prior studies document that higher financial reporting quality can enhance capital investment efficiency by mitigating capital underinvestment associated with financial constraints and capital over-investment associated with free cash flows by enhancing transparency (e.g., Biddle and Hilary 2006; McNichols and Stubben 2008; Hope and Thomas 2008; Biddle et al. 2009; Chen, Hope, Li, and Wang 2011; Cheng, Dhaliwal, and Zhang 2013; Chen, Young, and Zhuang 2013; Lo 2015; Biddle, Callahan, Hong, Knowles 2016), our findings indicate that countervailing actions taken by executives to clawback adoptions can decrease, rather than increase, capital investment efficiency even when financial reporting quality is enhanced by clawback provision adoptions. Finally, the increased likelihood of capital overinvestment associated with clawback adoptions differs from the well-documented empirebuilding proclivity in the sense that the former stems from a shift in capital investment mix that attempts to preserve incentive-based compensation whereas the latter is motivated by executives' direct preference for a larger salary associated with firm size irrespective of incentive alignment (Jensen 1986).

In Section 2 we present motivations and hypotheses. Section 3 details research design. Section 4 describes empirical results, and Section 5 summarizes and discusses our findings

\section{Motivating Evidence and Hypotheses}

\subsection{Prior research evidence regarding clawback provisions}

Incomplete information regarding executive activities and investment opportunities 
motivate earnings-linked executive compensation contracts that in turn provide executives with opportunities to manage earnings to influence their compensation (e.g., Jensen and Murphy 1990; Healy 1985; Cheng and Warfield 2005). Allegations that executives managed accounting accruals to inflate their compensation arising amid prominent firm failures in the early 2000 s (e.g., Enron, Worldcom, Global Crossing), led the U.S. Congress to sanctions restitutive clawbacks of executive compensation based on subsequently restated earnings in SarbanesOxley Act Section 304 (SOX 304, U.S. House of Representatives, 2002). Similar allegations of financial misreporting to raise executive pay during the 2008-2009 financial crisis motivated Dodd-Frank Act Section 954, (DFA 954, U.S. House of Representatives, 2010), which bars U.S. exchange listings by companies lacking clawback policies. Advocates of clawback provisions (see for example Chan et al. 2012, 2013 and Iskandar-Datta and Jia 2013) contend that clawback provisions will impose an incremental penalty on earnings restatements and thus enhance financial reporting quality. Despite subsequent confirming evidence profiled below, pending SEC Rule 10D-1 to implement DFA $954^{5}$ admits that "they may also alter operating decisions of executive officers" and requests "comment on any effect the proposed requirements may have on efficiency, competition and capital formation (SEC 2015, 103-104)." This study provides evidence regarding this question.

Prior research documents that clawback adoptions enhance financial reporting quality across a range of research paradigms. Chan et al. (2012) and Dehaan et al. (2013) find that

\footnotetext{
${ }^{5}$ Proposed SEC Rule 10D-1 authorizes recovery of excess incentive-based pay received by executive officers without regard to fault in the three fiscal years preceding the date a listed company is required to prepare an accounting restatement, where per Section 16 of the Exchange Act, executive officers include the company's president, principal financial officer, principal accounting officer, any vice-president in charge of a principal business unit, division or function, and any other person who performs policymaking functions for the company (Ackerman 2015; SEC 2015). It is estimated that Rule 10D-1 would apply to 4,845 registrants (SEC 2015, 108). Beyond the "Recovery of Erroneously Awarded Compensation" indicated in its title, the SEC anticipates that Rule 10D-1 will provide higher quality financial reporting by discouraging misreporting and "increased incentive to take steps to reduce the likelihood of inadvertent misreporting", for example by "devoting more resources to the production of high-quality financial reporting" (SEC 2015, 115).
} 
clawback adoptions reduce earnings restatements and auditors' reports of material internal control weaknesses, as well as reducing audit fees and hours. Dehaan et al. (2013) find clawback adoptions to decrease the frequency with which reported earnings meet or just beat consensus analysts' earnings forecasts. Babenko et al. (2015), Dehaan et al. (2013), Iskandar-Datta and Jia (2013), Chan et al. (2013), and Chen et al. (2014) find that investors respond favorably to voluntary clawback provisions, interpreting them as a pre-commitment to high-quality financial reporting. Dehaan et al. (2013), Chen et al. (2014), and Babenko et al. (2015) document an increase in the sensitivity of CEO annual pay to report earnings for clawback adopters, reflecting that boards perceive post-adoption earnings as more revealing regarding performance and executive efforts, consistent with the agency models in Goldman and Slezak (2006) and Laux and Laux (2009).

Higher quality financial reporting also reduces information asymmetry regarding the future payoffs and risks of investment projects (e.g., Healy and Palepu 2001; Leuz and Verrecchia 2000) thus helping to mitigate capital over- and under-investment (e.g., Biddle and Hilary 2006; McNichols and Stubben 2008; Hope and Thomas 2008; Biddle et al 2009; Chen et al. 2011; Cheng et al. 2013; Chen et al/ 2013; Lo 2015; Biddle et al. 2016). If clawback provisions enhance financial reporting quality, they should by these findings enhance capital investment efficiency unless offset by countervailing executive actions to preserve performance-linked compensation.

Other studies question whether clawback provisions enhance financial reporting quality. Denis (2012) argues that the reduction in earnings restatements reported by Chan et al. (2012) may reflect managers' attempt to avoid clawbacks, and that the reduction in audit efforts may reflect auditors' overconfidence of the positive anticipated effect of clawback provisions on financial reporting quality. Pyzoha (2015) experimentally finds that executives with a higher 
portion of incentive-based pay are less (more) likely to accept a lower (higher) quality auditor's proposed restatement. Fried and Shilon (2012), Babenko et al. (2015), and Erkens, Gan, and Yurtoglu (2014) find that clawback provisions are rarely enforced even when earnings restatements occur. Kyung et al. (2016) find that clawback adopters disclose lower-quality nonGAAP earnings more frequently than non-adopters do. Taken altogether, we interpret these findings as providing qualified support for clawback adoptions enhancing financial reporting quality.

Of particular interest are recent findings regarding the effects of clawback adoptions on R\&D expenditures and pay-performance sensitivity. Chan et al. (2015) find that managers respond to clawback adoptions by cutting discretionary expenses such as R\&D and advertising expenses to boost earnings and stock price performance, where this effect is stronger for firms with high investor-perceived growth potential and transient institutional ownership that provides managers with stronger incentives to achieve short-term earnings targets. As observed by Chan et al. (2015), this "real" versus accrual-based means of managing earnings less likely to be deemed improper by regulators and auditors (Ewert and Wagenhofer 2005; Graham, Harvey, and Rajgopal 2005; Roychowdhury 2006; Cohen, Dey, and Lys 2008). Because a reduction of R\&D expense is simultaneously a reduction of R\&D capital investment, this raises the question of how clawback adoptions relate more broadly to total capital investment, capital investment mix, and to capital investment efficiency.

Proposed Rule 10-1 (SEC 2015) specifically notes "an increased likelihood of an executive making inefficient operating decisions in order to affect specific financial reporting measures as a result of the decreased incentive to use accounting judgments to affect those financial reporting measures," with avoiding complicated projects and deferred R\&D investment as examples (SEC 
2015, 119, citing Babenko et al. (2015) and Chan et al. (2015)). In particular, the SEC observes that, "while the increased incentive to produce high-quality financial reporting and thus reduce the likelihood of material accounting errors should increase the informational efficiency of investment opportunities, it may also encourage executives to forgo value-enhancing projects if doing so would decrease the likelihood of a financial restatement" (SEC 2015, 118). These possible effects on capital investment decisions and capital investment efficiency are the focus of this study.

\subsection{Hypotheses}

Several theoretical studies regarding the interplays between performance-based compensation, earnings manipulation, and investment decision provide insight on the effects of clawbacks on earnings manipulation and investment decisions. Benmelech et al. (2010) analyses an agency model in which executives privately observe investment opportunities and provide financial reports to shareholders and boards of directors, while boards rely on reported earnings to evaluate the investment opportunities and provide executives with stock-based compensation. In this model, stock-based compensation not only induces executives to exert their efforts to develop and discover investment opportunities but also encourages earnings management to maintain the pretence of a high growth profile and avoid a stock price crash. ${ }^{6}$ In particular, executives may conceal a decline in growth opportunities and even forgo some profitable R\&D

\footnotetext{
${ }^{6}$ In a similar vein, Kedia and Philippone (2009) show that managers with private information on low productivity may manipulate earnings and overinvest at the same time to disguise the low true productivity and boost stock prices for their stock sale and option exercise. They model investing as a signalling device and earnings management enables investment despite low productivity. Laux (2014) presents a model in which boards provides executives with equity incentives and use reported earnings to decide whether to continue investment projects. In his model, a higher convexity in executive compensation enables managers to receive rewards only for good outcome (i.e., higher protection for downside risk), enhancing value-increasing efforts as well as earnings management and overinvestment.
} 
investment opportunities in order to show reported earnings consistent with a high growth rate. ${ }^{7}$ Furthermore, Benmelech et al. (2010, 1799) argue that clawback clauses that enable boards to recoup excess annual pay contingent on later restatement cannot eliminate executive incentives to manage earnings to preserve stock-based wealth and keep their jobs. ${ }^{8}$ This follows from incentives from changes in stock-based wealth and performance-based dismissal being generally larger than incentives from changes in annual pay (Jensen and Murphy 1990; Core, Guay, and Larcker 2003). To preserve their incentive-based compensation through earnings management, executives generally prefer accrual manipulation to real transactions manipulation because the former is less costly than the latter. However, clawback provisions increase the cost of accrual manipulation and therefore increases the choice of real transactions manipulation (Ewert and Wagenhofer 2005; Chan et al. 2015).

Our first hypothesis tests this insight by considering how clawback adoptions influence total capital investment and its mix of R\&D, capital expenditure, and acquisition components. Because they are immediately expensed, $R \& D$ investments reduce earnings immediately with generally delayed and less certain profitability paybacks (Bhagat and Welch 1995; Kothari et al. 2002; Coles et al. 2006). Capital expenditures by comparison reduce earnings via formulaic amortization and depreciation charges that depend on utilization, and generate nearer-term profits from generally extant business contexts. While acquisition investments can immediately enhance and may never reduce earnings depending on the profitability of firms whose control is obtained, they require enabling liquidity, integration with existing operations, and can require

\footnotetext{
${ }^{7}$ They originally show that executives forego some investment projects in order to use saved cash to maintain a high growth rate of dividend and argue that their results are consistent with cutting $R \& D$ expenses as part of real transactions manipulation documented by Graham et al. (2005). However, the reduction in R\&D envisaged by Benmelech et al. does not represent substitution between accrual manipulation and real transactions manipulation as a response to an increase in the cost of financial misreporting.

${ }^{8}$ Fried and Shilon (2012) point out that no clawback of excess stock-sale proceeds is a limitation of Dodd-Frank clawback requirements.
} 
lead-times to execute. ${ }^{9}$ Thus, when considered by their ability to substitute for accruals management constrained by clawback adoptions, capital expenditures and acquisitions hold potential to enhance income sooner than $R \& D$, with lead times more idiosyncratic for acquisitions; capital expenditures and acquisitions hold potential to enhance income with less uncertainty than $R \& D$, with acquisitions again more idiosyncratic; and capital expenditures and R\&D are generally more scalable, with acquisitions requiring enabling liquidity. Thus, beyond total capital investment, clawback adoptions may induce executives to change their mix of capital investments to influence performance-linked compensation. If clawback adoption leads to higher annual pay-earnings sensitivity as found by prior research, this will further amplify incentives for "real" earnings management that can include capital investments. ${ }^{10}$

Following from this reasoning, we propose hypothesis $\mathrm{H} 1$ in alternate form:

Hypothesis H1: Clawback provisions motivate capital investment mix shifts from $R \& D$ to capital expenditure and to acquisitions for firms with ample enabling liquidity.

When testing H1, we control for a range of determinants of capital investment identified in prior research (Biddle et al. 2009), including institutional investment, analysts, G-score, accrual quality, sales growth, asset size, market-to-book ratio, the standard deviations of cash flows, sales and investments, Z-score, tangibility, capital structure, financial slack, cash flows to sales, dividends, losses, firm age, and firm- and year-fixed effects (see Section 3 below for additional details).

Our second hypothesis tests whether the relations predicted by hypothesis $\mathrm{H} 1$ operate via performance-based executive compensation incentives. Specifically, H2 predicts that the

\footnotetext{
${ }^{9}$ Profits net of depreciation and amortization on write-ups to fair values of acquired depreciable assets under the purchase method of accounting for business combinations.

${ }^{10}$ Despite the risk of potential future clawback, the increase in pay-performance sensitivity may lead to an increase in accrual manipulation to some extent that such increase would not trigger future earnings restatements. Beyond that level, managers may increase the costly real activity manipulation.
} 
relations predicted by $\mathrm{H} 1$ will hold more strongly for a subset of clawback firms partitioned by a high proportion of performance-linked compensation, in alternate form as:

Hypothesis H2: Clawback provisions motivate capital investment mix shifts from R\&D expenditures to capital expenditures and to acquisitions for firms with ample enabling liquidity, for firms providing their CEOs with higher performance-based incentives.

Results consistent with hypothesis $\mathrm{H} 2$ provide assurance that the capital investment effects of clawback adoptions reflect performance-linked executive compensation incentives. We test hypothesis $\mathrm{H} 2$ using the same set of controls for capital investment as described above for hypothesis $\mathrm{H} 1$.

\section{Research Design}

\subsection{Sample selection}

Following Chan et al. (2012), we use the GMI Ratings database to identify firms that voluntarily adopt clawback provisions, and exclude financial firms because many are subject to clawbacks mandated by the Troubled Asset Relief Program (TARP). Accounting data are obtained from Compustat, stock price data from CRSP, corporate governance data from Risk Metrics and GMI Ratings, analyst coverage data from I/B/E/S, and institutional ownership data from Thompson Financial. We examine clawback adoptions during fiscal years 2005 through 2012 inclusive, which comprise more "voluntary" clawback adoptions amid progressive adoptions of DFA 954 provisions.

To control for differences in firm characteristics that may influence clawback adoptions and capital investment decisions, we follow Chan et al. (2013) to create a propensity-matched sample of firms that have not adopted clawback provisions but with a similar probability of adopting as a matched adopting counterpart. We do so by regressing an indicator variable for clawback 
adopters $($ Clawback $)$ on ex-ante economic determinants of clawback adoptions identified in prior studies $\left(X_{t-1}\right)$ :

$$
\text { Clawback }_{t}=\alpha_{0}+\sum \alpha_{\mathrm{i}} X_{t-1}+\varepsilon_{t},
$$

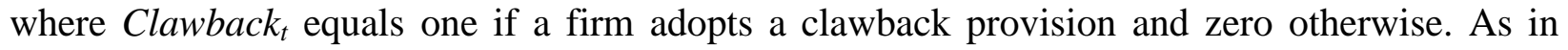
Chan et al. (2013), $X_{t-1}$ includes firm size, accounting profitability, the number of segments, prior restatements, a corporate governance index, board independence, audit committee size, the number of board meetings, institutional ownership, insider ownership, and CEO tenure in year $t-$ 1. Firm size and the number of segments reflect operational complexity effects on the ability of external stakeholders to monitor managerial behavior. The corporate governance and ownership variables reflect the intensity of monitoring and influence over managerial behavior. Prior restatements reflect incentives to restore credibility to financial reporting and $\mathrm{CEO}$ tenure reflects CEO influence within a firm.

Estimating Equation (1) by logistic regression for each fiscal year yields a propensity score for each firm-year in the predicted value of Clawback. We then match each clawback adoption firm-year with the non-adopting firm with the closest score in that year and within a distance of 0.01 from the adopting firm's propensity score. The pre- and post-adoption period for each firm spans $T-3$ to $T+3$ where $T$ is the adoption year for a clawback adopter and its propensity-scorematched counterpart. We use this time horizon to allow a sufficient length of time for managers to adjust the magnitude and mix of capital investments in response to clawback adoptions. ${ }^{11}$ To mitigate the influence of extreme outliers, we winsorize all continuous variables at the $1 \%$ and $99 \%$ levels.

\footnotetext{
${ }^{11}$ This time horizon is chosen to be sufficiently long to reveal how capital investments respond to clawback adoptions but not so long as to be confounded by other influences on capital investments.
} 


\subsection{Baseline relation between clawback adoptions and managerial incentives}

The boards of firms that adopt clawback clauses may change the other managerial incentive schemes. For example, boards may voluntarily adopt clawback clauses as part of a broader plan to tighten overall incentive-alignment in executive compensation or may increase a pay-weight on accounting profitability in anticipation of the enhanced reliability of earnings (Babenko et al. 2015; Dehaan et al. 2013; Chen et al. 2014). On the other hand, as clawback adoption makes incentive pay more risky, boards may reduce the use of incentive-based compensation (Denis 2012) or pay risk premium (Dehaan et al. 2013; Chen et al. 2014) in order to keep risk averse, competent managers. We thus allow that concurrent changes in executive compensation contracts can influence the firms' investment decisions.

We begin by exploring baseline relation between clawback adoptions and managerial incentives. First, we estimate changes in the sensitivities of executive annual pay flow to accounting-and market-based performance. To estimate the pay-performance sensitivity, we run the following regression model:

$$
\begin{aligned}
& \text { TotalPay }_{t}=\beta_{1} \text { Post }_{t}+\beta_{2} \text { Clawback }_{t} \times \text { Post }_{t}+\beta_{3} \text { ROA }_{t}+\beta_{4} \text { Clawback }_{t} \times \text { ROA }_{t} \\
& +\beta_{5} \text { Post }_{t} \times \text { ROA }_{t}+\beta_{6} \text { Clawback }_{t} \times \text { Post }_{t} \times \text { ROA }_{t}+\sum \beta_{i} \text { Controls }_{t} \\
& +\sum \beta_{i} \text { Controls }_{t} \times \text { Clawback }_{t}+\sum \beta_{i} \text { Controls }_{t+1} \times \text { Post }_{t} \\
& +\sum \beta_{i} \text { Controls }_{t} \times \text { Clawback }_{t} \times \text { Post }_{t}+\text { Fixed Effects }+\varepsilon_{t} .
\end{aligned}
$$

In Equation (2), TotalPay $t$ is the logarithm of one plus CEO annual total pay for year $t^{12}$, and we adjust the annual total pay (ExecuComp TDC1) for inflation using the U.S. Consumer Price Index. $R O A_{t}$ is accounting return on assets for year $t$, and $R E T_{t}$, is 12 -month stock returns. Coefficient $\beta_{3}$ indicates the base sensitivity of $\mathrm{CEO}$ annual total pay to $R O A$. Coefficient $\beta_{6}$ for interaction term Clawback $\times$ Post $\times$ ROA indicates the incremental change in pay-earnings

\footnotetext{
${ }^{12}$ Base salary is determined at the employment contract date and rarely adjusted based on performance. In contrast, the amount of bonus, stock and option grants for year $t$ is largely based on the CEO's performance for year $t$ and approved after the end of year $t$.
} 
sensitivity subsequent to clawback adoptions. We also estimate the same regression for equity grants (i.e., stock and option grants) and cash pay (i.e., salary and bonus). Control variables follow Core, Holthausen, and Larcker (1999) and include firm performance volatility measured by the standard deviations of $R O A$ and $R E T$ estimated over the prior five years $\left(V O L R O A_{t}\right.$ and $V_{V L R E T_{t}}$ ); growth opportunities measured using average market-to-book equity ratio estimated over the prior five years $\left(M T B_{t}\right)$; and demand for incremental efforts and ability required to manage a firm with a larger firm size measured by the logarithm of sales during year $t$ $\left(\operatorname{LOGSALE}_{t}\right) \cdot{ }^{13}$ We further include firm- and year-fixed effects in Equation (2) to control for cross-sectional variation in CEO annual pay associated with omitted time-invariant firm characteristics and inter-temporal changes in CEO annual pay associated macroeconomic effects, respectively.

Second, we estimate changes in the composition of CEO annual total pay (e.g., percentage of performance-based pay in total pay) and the risk-tolerating incentive associated with CEO firm-specific equity portfolio. In particular, we estimate the following regression Equation (3):

IncentiveVar $_{t}=\beta_{1}$ Post $_{t}+\beta_{2}$ Clawback $_{t} \times$ Post $_{t}+\sum \beta_{i}$ Controls $_{t}+$ Fixed Effects $+\varepsilon_{t}$

where IncentiveVar ${ }_{t}$ refers to the compensation incentive variables: (a) SalaryRatio , defined as $^{2}$

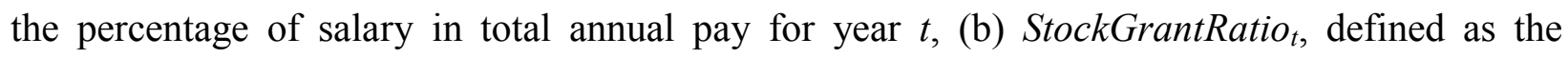
percentage of stock grants in total annual pay for year $t$, (c) OptionGrantRatio , defined as the percentage of option grants to total annual pay for year $t$, and (d) RiskTolerance $t_{t}$, defined as risktolerating incentive related to CEO equity portfolio for year $t$ and measured as $\operatorname{Veg} a_{t} \times 100 /$

\footnotetext{
${ }^{13}$ Following Harford and Li (2007), we augment Equation (2) by employing sales growth as another performance measure and decomposing stock returns into positive and negative ones. The impact of clawback adoption on the annual pay-ROA sensitivity remains identical with $R$-squares significantly reduced. We also re-estimated Equation (2) for a subsample of non-turnover observations and obtain qualitatively identical results.
} 
$\left(\operatorname{Vega}_{t}+\right.$ Delta $\left._{t}\right)$. Following Core and Guay (2002) and Coles et al. (2006), we measure Delta as a dollar change in CEO equity portfolio by one percentage point and Vega as a dollar change in CEO equity portfolio by 0.01 change in the standard deviation of stock returns, respectively. If CEOs are risk averse and cannot diversify away their firm-specific wealth, a higher (lower) level of Vega relative to Delta will encourage them to undertake more (less) risky investment projects. Coles et al. (2006) find that Vega is negatively related to capital expenditure (producing less uncertain financial outcome) and positively to $R \& D$ expenditures (producing more uncertain financial outcome) after controlling for Delta, suggesting that Vega increases managers' risk taking. We further allow for a tradeoff between pay convexity, earnings management, and investment efficiency considered by Laux (2014). In his model, the shift to a more convex pay (e.g., more option grants and less stock grants) is positively associated with value-enhancing efforts but negatively with financial reporting quality and investment efficiency. Controls and Fixed effects in Equation (3) are the same as those in Equation (2) and are not interacted with indicator variables Post, Clawback, and Clawback $\times$ Post.

\subsection{Relation between clawback adoptions and shift in capital investment mix}

Hypothesis H1 predicts that clawback adopters will shift capital investment mix from R\&D to capex following clawback adoptions. To test this hypothesis, we estimate the relations between clawback adoptions and capital investment by type using Equation (4):

$$
\text { InvVar }_{t+1}=\gamma_{1} \text { Post }_{t}+\gamma_{2} \text { Clawback }_{t} \times \text { Post }_{t}+\sum \gamma_{i} \text { Control }_{t}+\text { Fixed Effects }+\varepsilon_{t},
$$

where InvVar ${ }_{t+1}$ refers to the investment policy variables: (a) Investment $t_{t+1}$, defined as total capital investment (measured as the sum of capital expenditures, acquisitions, and R\&D expenditures less sales of property, plant and equipment) for year $t+1$ multiplied by 100 and scaled by total assets at the end of year $t$; (b) Acquisition $_{t+1}$, defined as acquisitions for year $t+1$ 
multiplied by 100 deflated by total assets at the end of year $t$; (c) Capex $_{t+1}$, defined as capital expenditures for year $t+1$ multiplied by 100 deflated by total assets at the end of year $t$; and (d) $R \& D_{t+1}$, defined as research and development expenditures for year $t+1$ multiplied by 100 deflated by total assets at the end of year $t .^{14}$

Following prior studies (e.g., Biddle and Hillary 2006; Biddle et al. 2009), we control for year $t$ firm characteristics associated with capital investment and financial constraints using: (a) proxies for investment opportunities measured by sales growth (SalesGrowth) and Tobin's Q (Mkt-to-Book); (b) indicators of financial constraints measured by operating cash flows (CFOsale), financial slack (Slack), firm- and industry-average capital structure ( $K$-structure and Ind-K-structure, respectively), and dividend payout ratio (Dividend); (c) bankruptcy risk and cost measured by the standard deviation of operating cash flows (Std-cfo), the standard deviation of sales (Std-sales), Z-score (Z-score), tangibility (Tangibility), and an indicator for operating losses (Losses); (d) the intensity of internal and external monitoring proxied by the corporate governance index ( $g$-index), an indicator for missing g-index values (G-Dummy), institutional ownership (Institutions), and analyst coverage (Analysts); and (e) other related firm characteristics measured by firm size (LogAsset), firm age (Age), operating cycle (OperatingCycle), accrual quality $(A Q)$, and the standard deviation of total investment (StdInvestment) ${ }^{15}$ We further control for firm- and year-fixed effects in Equation (4).

In Equation (4), coefficient $\beta_{1}$ on Post reflects the average difference in unexpected capital

14 Not all R\&D expenditures are expensed, but US accounting principles (ASC 730) permit only limited exceptions; IFRS guidance (IAS 38) requires R\&D capitalization under limited conditions, but foreign firms listed in the US, for which IFRS is a reporting option, constitute only $1.9 \%$ of our sample firm-years. In either case this would bias against our findings and the untabulated result of a sensitivity test confirms that our results remain qualitatively identical with foreign US listers excluded.

${ }^{15}$ Some of these control variables are used in prior studies to measure risk-taking. For example, firm size, the market-to-book ratio, capital structure, the standard deviations of cash flows and sale, an indicator variable for losses, and/or z-score are used by Coles et al. (2006) and Bargeron, Lehn and Zutter (2010). See Appendix Table A1 for a complete list of variable definitions and measures. 
investment of non-adopters between the pre- and post-adoption periods. Coefficient $\beta_{2}$ on Clawback $\times$ Post indicates the incremental effect of clawback adoption on unexpected capital investment, which $\mathrm{H} 1$ predicts to be positive and significant for capital expenditures (Capex $\left.t_{t+1}\right)$ and negative and significant for $\mathrm{R} \& \mathrm{D}$ expenditures $\left(R \& D_{t+1}\right)$.

Hypothesis $\mathrm{H} 2$ predicts that these relations will be enhanced for clawback adopters with higher performance-based pay. To test this hypothesis, we estimate Equation (4) for two subgroups partitioned by the percentage of performance-based pay in total pay. We classify as HighPerfPay (LowPerfPay) firms if their mean ratio of non-salary pay to total pay during three years immediately following the clawback adoption year is higher (lower) than the sample median. ${ }^{16}$ Since concurrent changes in the convexity in CEO firm-specific equity portfolio have no theoretical causal relations to clawback adoptions, we include the variable RiskTolerance in the subsample regression to control for potential changes in capital investment mix induced by changes in the convexity in $\mathrm{CEO}$ equity portfolio value.

\subsection{Relation between clawback adoptions and capital investment efficiency}

If the shift in capital investment following clawback adoptions estimated by Equation (4) occurs for earnings management, such a shift is likely to constitute inefficient investment that deviates from a level justified by investment opportunities. Thus, we examine whether the shift in capital investment mix following clawback adoptions is related to capital investment efficiency in two steps. First, we estimate deviations from expected capital investment by estimating the following regression for all Compustat non-financial firms with available data for our entire sample period:

$$
\text { InvVar }_{t+1}=\gamma_{0}+\gamma_{1} \times \text { SalesGrowth }{ }_{t}+\gamma_{2} \times \text { Mkt-to-Book }{ }_{t}+\text { Fixed Effects }+\varepsilon_{t}
$$

\footnotetext{
${ }^{16}$ When the partition is based on whether the mean ratio of non-salary pay to total pay during three years immediately before the clawback adoption year exceeds the sample median, the results remain qualitatively identical.
} 
where InvVar ${ }_{t+1}$ refers to the investment policy variables for year $t+1$, SalesGrowth ${ }_{t}$ and Mkt-to$B o o k_{t}$ are proxies for firm-level investment opportunities for year $t$, and Fixed effects represent the variations in capital investment associated with time-invariant industry-specific factors and time-varying macroeconomic factors. We then estimate the residual of each regression and generate its quartiles. We define an indicator variable for overinvestment (i.e., Overinvesting ${ }_{t+1}$ ) equals to one if the residual is in the upper 25 percentile and zero if the residual is between the 25 and 75 percentiles. Similarly, we define an indicator variable for underinvestment (i.e., Underinvesting $\left._{t+1}\right)$ that equals one if the residual is in the lower 25 percentile and zero if the residual is between the 25 and 75 percentiles. The underlying assumption in measuring overinvesting (underinvesting) in this manner is that the significantly high (low) level of unexpected investment beyond (below) that explained by firm-level investment opportunities and industry- and year-specific factors can be regarded as overinvesting (underinvesting).

Next, we assess the effects of clawback adoptions on capital investment efficiency by estimating the following logistic regression:

Overinvesting $_{t+1}\left(\right.$ Underinvesting $\left._{t+1}\right)=\delta_{0}+\delta_{1} \times$ Clawback $_{t}+\delta_{2} \times$ Post $_{t}+\delta_{3} \times$ Clawback $_{t} \times$ Post $_{t}$

$$
+\sum \delta_{i} \times \text { Controls }_{t}+\text { Fixed Effects }+\varepsilon_{t}
$$

Equation (6) is estimated using the same control variables as for Equation (4), and controls for industry-fixed effects (based on SIC two-digit codes) and year-fixed effects. The coefficient on Post,$\delta_{2}$, captures an average change in the propensity of non-adopters to overinvest (underinvest) following clawback adoptions. The coefficient on Clawback $\times$ Post, $\delta_{3}$, reflects an average incremental change in the propensity of clawback adopters to overinvest (underinvest) following clawback adoptions. Finally, in Section 4.5 below we describe a validating test for whether acquisition capital investments are enhanced by enabling liquidity of clawback adopters. 


\section{Empirical Results}

\subsection{Sample distribution and descriptive statistics}

Table 1 describes sample clawback adopters obtained from the Corporate Library data set that exclude financial firms as described above. Panel A shows year of clawback adoption and cumulative adopters by year during the sample period of 2005 through 2012 inclusive. Panel B describes sample selection. Panel A reveals clawback adoptions to generally increase year-onyear during the sample period, rising from 19 in 2005 to 209 in 2012, with 56\% $(588 / 1,032)$ of new clawback adopters (versus sample firm years that depend on data availability) between 2010 and 2012 inclusive. In Panel B, propensity score matching is applied as described above to select 966 control firms from among 3,566 non-financial firms that did not adopt clawback clauses between 2005 and 2012 inclusive, which after omitting observations beyond year $T-3$ to $T+3$ (where year $T$ is the clawback provision adoption year), yields a final sample of 4,200 firm-year observations comprised of 2,188 observations for 463 clawback adopters and 2,012 observations for 429 non-adopters. The final sample is used to test the effect of clawback provision on capital investment mix. A sub-sample of 3,111 firm-year observations (1,674 observations for 357 clawback adopters and 1,437 observations for 312 non-adopters is used to examine concurrent changes in executive compensation. ${ }^{17}$

Table 2 presents descriptive statistics for firm-years with available data in Table 1. Shown are means, standard deviations, medians, and $p$-values for mean and median differences between clawback adopters and non-adopters for each test and control variable for 3,111 firm-year observations for the CEO compensation regression variables (Panel A) and 4,200 firm-year observations for the investment regression variables (Panel B). Notably for the CEO

\footnotetext{
${ }^{17}$ The sub-sample is an intersection of the GMI ratings dataset and the Execucomp dataset, with some observations missing due to missing values for compensation and determinants.
} 
compensation regression variables, statistically significant mean differences are observed for the market-to-book ratio averaged over the previous five years $(M T B)$ and the risk-tolerance incentive related to CEO equity holdings (RiskTolerance), which are higher for non-adopters. Non-adopters also exhibit lower mean total investment, acquisitions, median R\&D expenditures, mean and median frequency of ample liquidity (AmpleCash) than clawback adopters.

\subsection{Associations between clawback adoptions and managerial incentives}

We begin by documenting for our sample concurrent changes in executive compensation incentives that may influence clawback adoption responses. Table 3 documents average changes in managerial incentives associated with clawback adoptions. Panel A indicates that CEO annual total pay and CEO annual equity grants (but not CEO annual cash pay) become more sensitive to return on assets (but not to stock returns) following clawback adoptions, consistent with prior evidence in Babenko et al. (2015), Chen et al. (2014), and Dehaan et al. (2013). ${ }^{18}$ As seen in the statistical significance for the ROA coefficient and the RET coefficient in all three columns, average positive pay-performance sensitivity is indicated for non-adopters. ${ }^{19}$ In columns (1) and (2), the significant positive coefficient for Clawback $\times$ Post $\times R O A$ and insignificant coefficient for Clawback $\times$ Post $\times$ RET indicates that the CEO annual total pay and CEO equity grants of clawback adopters become more sensitive to return on assets but not to stock returns after clawback adoptions. These results are consistent with the argument in prior studies that boards perceive accounting-based performance to become more reliable as measures of CEO effort following clawback adoptions. Untabulated results indicate that the increase in the sensitivity of

\footnotetext{
${ }^{18}$ Among the results of prior studies, those of Chen et al. (2014) are closest to ours. They find an increase in the sensitivity of CEO total pay and CEO total incentive pay (bonus plus equity grants) to return on assets. Dehaan et al. (2013) report an increase in the sensitivity of change in cash pay to a positive change in return on assets but not to a negative change in return on assets.

${ }^{19}$ In Column (1), the insignificant coefficients for Clawback $\times R O A$ and Clawback $\times$ RET indicate an insignificant difference in the CEO pay-performance sensitivity between clawback adopters and non-adopters in the pre-adoption period.
} 
CEO annual total pay to ROA is significant, regardless of whether ROA increases or decreases from year $t-1$ to year $t$. This hightened pay-earnings sensitivity should amplify the incentive to manage earnings in order to preserve executive compensation following a clawback adoption.

Prior research reports mixed evidence regarding whether boards pay risk premia to offset increased compensation risk due to clawback adoptions. ${ }^{20}$ Consistent with the finding of DattaIskandar and Jia (2013), Panel A of Table 3 shows insignificant coefficients on Post and Clawback $\times$ Post, indicating that the boards of clawback firms do not pay such risk premium to CEOs. Panel B of Table 3 reports estimated effects of clawback adoptions on the composition of CEO total pay and the sensitivity of CEO equity portfolio to stock price changes. The results indicate that both the percentage of option grants in total pay (OptiongrantRatio) and the risktolerating incentive (RiskTolerance) decrease following clawback adoptions, suggesting that the boards of clawback firms decrease convexity in CEO compensation to reduce managers' risktaking incentives. ${ }^{21}$ Consistent with the results in Panel B of Table 3, untabulated results indicate that Vega is negatively associated with clawback adoptions, after controlling Delta. In contrast, clawback adoptions do not significantly change the percentage of stock grants in total pay and the percentage of salary in total pay. ${ }^{22}$

Table 4 presents the results of estimating Equations 2 and 3 for sub-samples partitioned by relatively high and low performance-based pay (based on whether average ratio of non-salary pay to total pay during the three years immediately after the clawback-adoption year is higher

\footnotetext{
${ }^{20}$ Dehaan et al. (2013) and Chen et al. (2014) find positive risk premium paid to the CEOs of clawback adopters after controlling for the economic determinants for expected CEO pay. In contrast, Iskandar-Datta and Jia (2013) find no reliable evidence that indicates such risk premium.

${ }^{21}$ The decrease in convexity in CEO firm-specific equity portfolio may be caused by the reduction in the weight of option grants in total pay, the exercise of option holdings, and other changes in variables in the Black-Sholes formula.

${ }^{22}$ The risk-tolerating incentive represents how much more sensitive the value of CEO equity portfolio is to a change in stock return volatility than to a change in stock returns. If a CEO is risk averse and he or she owns a considerable amount of stocks and options, the relative sensitivity can capture the CEO's risk-taking or risk-tolerating incentive in investment decisions. See Appendix for detailed definition.
} 
than its sample median). These results indicate that the increase in pay-performance sensitivity (Panel A) and the reduction of the percentage of option grants in total pay and the risk-taking incentive related to CEO equity portfolio (Panel B) are found for clawback firms with relatively high performance-based pay and not for clawback firms with relatively low performance-based pay.

Overall, the results in Tables 3 and 4 suggest that boards voluntarily adopt clawback provisions as part of a broader plan to enhance the reliability of accounting-based performance, tighten the sensitivity of CEO pay to accounting performance, and reduce risk-taking incentive (i.e., lower convexity in CEO compensation). The concurrent changes in other incentive schemes are thus unlikely to produce counter-factual effects invalidating our hypotheses. This implication differs from a criticism of Dodd-Frank Section 954 mandatory clawback provisions that they make incentive-based pay more risky and may induce firms to reduce the use of incentive-based compensation and the incentive-alignment benefits of such compensation (Denis 2012).

\subsection{Associations between clawback adoptions and next-period capital investments}

Table 5 presents the results of estimating Equation (4) relating capital investment in total and by type to clawback adoptions for the combined 4,200 firm-year study sample of clawback adopters and non-adopters. The results support our hypothesis H1 that clawback adoptions induce more capital expenditures and less R\&D expenditures. For total capital investment, the coefficient on Clawback $\times$ Post is positive but insignificantly different from zero, indicating that clawback adoptions are not associated with a significant increase in total capital investment. However, the coefficient on Clawback $\times$ Post for R\&D investment is significantly negative, consistent with Chan et al. (2015). If R\&D investment decreases but total capital investment does not significantly change, it thus begs how capital investment mix shifted without compromising 
the size of operation controlled by managers and firm growth profile that are linked to their compensation. As seen in the positive and statistically significant coefficient on Clawback $\times$ Post for Capex, a shift is made by clawback adopters away from $R \& D$ capital investment and toward Capex investment. The coefficient on Clawback $\times$ Post for acquisition capital investment is not significantly different from zero for the combined study sample.

Table 6 presents estimates for Equation (4) relating capital investment in total and by type when applied to two sub-samples partitioned into relatively high and low performance-based pay. As in Table 5, statistically significant reductions in R\&D and statistically significant increases in capital expenditures are again observed, but only for the high performance-based pay partition, after controlling for the confounding effects of concurrent changes in RiskTolerance. ${ }^{23}$ The result supports $\mathrm{H} 2$ that clawback adoption imposes greater incentives for managers to preserve performance-based compensation by shifting the capital investment mix.

\subsection{Clawback adoptions and capital investment efficiency}

Table 7 presents estimates using Equation (6) to examine whether the shift in capital investment mix is related to the likelihood of inefficient capital investment. Panel A of Table 7 reports the relation between clawback adoptions and the likelihood of overinvesting (i.e., top quartile of unexpected investment) versus benchmark (i.e., two middle quartiles of unexpected investment) for the test sample. The coefficient for Clawback $\times$ Post is significantly positive only for capital expenditures, indicating that clawback adopters are more likely to overinvest in property, plant, and equipment after clawback adoptions.

Panel B of Table 7 shows the relation between clawback adoptions and the likelihood of overinvesting versus benchmark for two subsamples partitioned by the percentage of

\footnotetext{
${ }^{23}$ When the variable RiskTolerance is replaced with Vega and Delta or omitted, the shift in capital investment mix remains qualitatively identical.
} 
performance-based pay in annual total pay. As in Table 6, we control for the confounding effects of concurrent changes in risk-tolerating incentives on the likelihood of overinvestment. For both total capital investment and capital expenditures, the coefficient on Clawback $\times$ Post is significantly positive for a subgroup of clawback adopters providing relatively high performance-based pay (HighPerfPay), indicating that the overinvestment in property, plant, and equipment is prominent for firms using high performance-based compensation. ${ }^{24}$ The increased total capital overinvestment for firms with high performance-based compensation also suggests that given high performance-based compensation, clawback adoptions induce executives to increase the size of operation as a "real" means to influence executive compensation. Combined, these results serve to confirm a positive association between clawback adoptions and capital overinvesting via a managerial incentive channel. ${ }^{25}$

\subsection{Corroborating tests}

\subsubsection{Effects of clawback adoptions on capital investment and firm liquidity}

As discussed in Section 2, capital investment mix shifts to acquisition expenditures can potentially generate immediate profits and executive compensation related to firm size, but also require enabling liquidity, with firms with less enabling liquidity less able to affect them. This reasoning suggests that capital investment mix shifts to acquisitions induced by clawback adoptions will be more prevalent for firms with ample liquidity. We test this reasoning by examining relations between clawback adoptions and capital investment by type conditional on a variable that measures acquisition-enabling liquidity. Acquisition-enabling liquidity reflects an equal weighting of cash and cash equivalents scaled by total assets, to reflect ability to effect

\footnotetext{
${ }^{24}$ These results are robust to the replacement of RiskTolerance with Vega and Delta and to the omission of RiskTolerance from the logistic regressions.

${ }^{25}$ We correspondingly examine whether the reduction in R\&D expenditures following clawback adoptions reported by Tables 5 and 6 is positively associated with the likelihood of underinvesting in R\&D projects, but we did not find systematic evidence of this conjecture perhaps due to limited sample size (untabulated).
} 
acquisitions in the short term, and (the negative of) financial leverage among all Compustat firms with available data in a given year, to reflect financing ability (following Biddle et al. 2009). We then classify as AmpleCash (Short-Cash) firms a group of firms with top 20\% (bottom 80\%) of this average rank during three years immediately before the adoption year, so as to better reflect ample and limited liquidity, termed AmpleCash and ShortCash, respectively.

Results for Equation 4 estimated with conditioning for acquisition-enabling liquidity are reported in Table 8. The coefficients for both Clawback $\times$ Post $\times$ AmpleCash and Clawback $\times$ Post $\times$ ShortCash are insignificantly different from zero, indicating as above that clawback adoptions also have no significant effect on total capital investment for extreme high- and lowliquidity firms. However, the coefficient for Clawback $\times$ Post $\times$ AmpleCash is positive and significant for Acquisitions and insignificantly different from zero for Capex and $R \& D$. The coefficient for Clawback $\times$ Post $\times$ ShortCash is insignificantly different from zero for all three capital investment components. These findings are consistent with clawback adoptions inducing (not inducing) capital investment mix shifts toward acquisitions for firms with ample (limited) enabling liquidity, with little substitution away from capex and R\&D expenditures as explained by having ample (limited) liquidity. ${ }^{26}$

\subsubsection{Effects of clawback adoptions on capital investment and growth opportunities}

In developing our hypotheses, we posit that managers respond to clawback adoptions by shifting capital investment mix in order to maintain the pretense of strong growth opportunities (Benmelech et al. 2010), a condition for which Skinner and Sloan (2002) show greater market responses to missing earnings targets. Chan et al. (2015) find that clawback firms are more likely to engage in real transactions manipulation when the market to book ratio, a proxy for market-

\footnotetext{
${ }^{26}$ Ample liquidity firms can undertake acquisitions with less need to reduce $R \& D$ expenditures if acquisitions countervail the performance-linked compensation effects of clawback adoptions, whereas firms with limited liquidity are less enabled to undertake capital investment mix shifts.
} 
perceived growth opportunities, is higher. We validate this premise by estimating Equation (4) relating capital investment in total and by type when applied to two sub-samples partitioned into firms with relatively high and low market-perceived growth opportunities following Chan et al. (2015). ${ }^{27}$ As in Table 5, Table 9 presents statistically significant reductions in R\&D and statistically significant increases in capital expenditures, but only for the high growth partition. Thus, a capital investment mix shift from $R \& D$ to capital expenditures for clawback adopters is more prominent for clawback adopters with relatively high market-perceived growth potential, once again consistent with greater incentives to preserve performance-linked compensation.

\section{Conclusions}

This study examines whether capital investments are influenced by voluntary adoptions of clawback provisions that authorize boards of directors to recoup from company executives compensation based on restated financial results. We find that clawback adoptions induce capital investment mix shifts from R\&D expenditures to capital expenditures, particularly for firms providing relatively high performance-based pay, consistent with pay-linked incentives. We also find that this shift in capital investment mix is related to overinvestment beyond an expected level supported by investment opportunities. Corroborative tests confirm that the shift from R\&D to capital expenditure is more prominent for clawback firms with relatively high marketperceived growth opportunities and that acquisition expenditures also increase for clawback firms with ample liquidity.

These findings contribute to emerging evidence regarding the effects of clawback clauses that considers managerial responses to their adoptions. Extending prior evidence that clawback adoptions induce managers to cut $\mathrm{R} \& \mathrm{D}$ expenses to boost reported earnings, our findings reveal

\footnotetext{
${ }^{27}$ To elaborate, firms with average rank of market-to-book ratios during the three years prior to clawback adoption higher (lower) than the sample median are classified as firms with high (low) growth opportunities.
} 
that R\&D reductions documented in Chan et al. (2015) comprise part of a broader capital investment mix shift toward capital expenditures and acquisitions, conditional on enabling liquidity, and capital overinvestment that relate to managerial compensation incentives. As such, our results extend prior findings regarding perhaps unintended consequences of mandatory clawback adoptions that can inform their proposed condition for U.S. exchange listings that invites comments regarding possible effects. As such, this study extends the empirical literature on the relation between financial reporting quality and capital investment efficiency by adding evidence of the overinvestment in property, plant, and equipment driven by "real" earnings management to preserve performance-based compensation. This evidence is timely given pending SEC rule that would mandate clawback provisions for all firms listing on US exchanges and its call for "comment on any effect the proposed requirements may have on efficiency, competition and capital formation (SEC 2015, 103-104)." 


\section{References}

Ackerman, A., 2015. SEC proposes rule on "clawback" policies. Wall Street Journal (August 12, 2015).

Altman, E., 1968. Financial ratios, discriminant analysis and the prediction of corporate bankruptcy. Journal of Finance 23, 189-209.

Babenko, I., Bennett, B., Bizjak, J.M., Coles, J.L., 2017. Clawback provisions. Working paper, University of Utah.

Bargeron, L.L., Lehn, K.M., Zutter, C.J. 2010. Sarbanes-Oxley and corporate risk-taking. Journal of Accounting and Economics 49 (1), 34-52.

Benmelech, E., Kandel, E., Veronesi, P. 2010. Stock-based compensation and CEO (dis) incentives. The Quarterly Journal of Economics 125 (4), 1769-1820.

Bhagat, S., Welch, I., 1995. Corporate research \& development investments: International comparisons. Journal of Accounting and Economics 19, 443-470.

Biddle, G., Hilary, G., 2006. Accounting quality and firm-level capital investment. The Accounting Review 81, 963-982.

Biddle, G., Hilary, G., Verdi, R., 2009. How does financial reporting quality relate to investment efficiency? Journal of Accounting and Economics 48, 112-131.

Biddle, G., Callahan, C., Hong, H., Knowles, R., 2016. Do adoptions of international financial reporting Standards enhance capital investment efficiency? Working paper, University of Hong Kong.

Chan, L.H., Chen, K.C.W., Chen, T.-Y., 2013. The effects of firm-initiated clawback provisions on bank loan contracting. Journal of Financial Economics 110, 659-679.

Chan, L.H., Chen, K.C.W., Chen, T.-Y., Yu, Y., 2012. The effects of firm-initiated clawback provisions on earnings quality and auditor behavior. Journal of Accounting and Economics 54 (2), 180-196.

Chan, L.H., Chen, K.C.W., Chen, T.-Y., Yu, Y., 2015. Substitution between real and accrualsbased earnings management after voluntary adoption of compensation clawback provisions. The Accounting Review 90 (1), 147-174.

Chen, F., Hope, O.-K., Li, Q., Wang, X., 2011. Financial reporting quality and investment efficiency of private firms in emerging markets. The Accounting Review 86 (4), 1255-1288.

Chen, C., Young, D., Zhuang, Z., 2013. Externalities of mandatory IFRS adoption: Evidence from cross-border spillover effects of financial information on investment efficiency. The Accounting Review 88 (3), 881-914.

Chen, M.A., Greene, D. T., Owers, J.E., 2014. The costs and benefits of CEO clawback provisions. Review of Corporate Finance Studies, 10.1093/rcfs/cfu012.

Chen, X., Cheng, Q., Lo, A., Wang, X., 2015. CEO contractual protection and managerial shorttermism. The Accounting Review 90 (5), 1871-1906.

Cheng, M., Dhaliwal, D., Zhang, Y., 2013. Does investment efficiency improve after the disclosure of material weaknesses in internal control over financial reporting? Journal of Accounting and Economics 56, 1-18. 
Cheng, Q., Warfield, T.D. 2005. Equity incentives and earnings management. The Accounting Review 80 (2), 441-476.

Cohen, D.A., Dey, A., Lys, T.Z., 2008. Real and accrual-based earnings management in the preand post-Sarbanes-Oxley periods. The Accounting Review 83 (3), 757-787.

Coles, J.L., Daniel, N.D., Naveen, L., 2006. Managerial incentives and risk taking. Journal of Financial Economics 79, 431-468.

Core, J.E., Guay, W., 2002. Estimating the value of employee stock option portfolios and their sensitivities to price and volatility. Journal of Accounting Research 40 (3), 613-630.

Core, J.E., Holthausen, R.W., Larcker, D.F., 1999. Corporate governance, chief executive officer compensation, and firm performance. Journal of Accounting and Economics 51, 371-406.

Dechow, P., Dichev, I., 2002. The quality of accruals and earnings: The role of accrual estimation errors. The Accounting Review 77, 35-59.

Dehaan, E.D, Hodge, F., Shevlin, T., 2013. Does voluntary adoption of a clawback provision improve financial reporting quality? Contemporary Accounting Research 30 (3), 10271062.

Denis, D.K., 2012. Mandatory clawback provisions, information disclosure, and the regulation of securities markets. Journal of Accounting and Economics 54 (2), 197-200.

Erkens, M., Gan, Y., Yurtoglu, B., 2014. Firm-level heterogeneity of clawback provisions. In: Academy of Management Proceedings. Academy of Management, 14194.

Ewert, R., Wagenhofer, A., 2005. Economic effects of tightening accounting standards to restrict earnings management. The Accounting Review 80, 1101-1124.

Fama, E., French, K., 1997. Industry costs of equity. Journal of Financial Economics 43 (2), 153-193.

Fried, J. M., Shilon, N., 2012. Execess pay clawbacks. The Journal of Corporate Law 36 (4), $722-751$.

Goldman, E., Slezak, S.L., 2006. An equilibrium model of incentive contracts in the presence of information manipulation. Journal of Financial Economics 80 (3), 603-626.

Gompers, P., Ishii, J., Metrick, A., 2003. Corporate governance and equity prices. Quarterly Journal of Economics 118, 107-155.

Graham, J.R., Harvey, C.R., Rajgopal, S., 2005. The economic implications of corporate financial reporting. Journal of Accounting and Economics 40, 3-73.

Guay, W. R., Core, J.E., Larcker, D. F., 2003. Executive Equity Compensation and Incentives: A Survey, Economic Policy Review 9 (1), 27-50

Harford, J., Li, K. 2007. Decoupling CEO wealth and firm performance: The case of acquiring CEOs. The Journal of Finance 62 (2), 917-949.

Healy, P.M. 1985. The effect of bonus schemes on accounting decisions. Journal of Accounting and Economics 7 (1-3), 85-107.

Healy, P.M., Palepu, K.G., 2001. Information asymmetry, corporate disclosure, and the capital markets: A review of the empirical disclosure literature. Journal of Accounting and Economics 31, 405-440. 
Hope, O.-K., Thomas, W., 2008. Managerial empire building and firm disclosure. Journal of Accounting and Research 46 (3), 591-626.

Iskandar-Datta, M., Jia, Y., 2013. Valuation consequences of clawback provisions. The Accounting Review 88 (1), 171-198.

Jensen, M.C., 1986. Agency costs of free cash flow, corporate finance, and takeovers. The American Economic Review 76 (May), 323-329.

Jensen, M. C., Murphy, K.J. 1990. Performance pay and top-management incentives. Journal of Political Economy 98 (2), 225-264.

Kedia, S., Philippon, T., 2009. The economics of fraudulent accounting. The Review of Financial Studies 22 (6), 2169-2199.

Kothari, S.P., Laguerre, T.E., Leone, A.J., 2002. Capitalization versus expensing: Evidence on the uncertainty of future earnings from capital expenditures versus R\&D outlays. Review of Accounting Studies 7, 355-382.

Kyung, H., Lee, H., Marquardt, C., 2016. The effect of voluntary clawback adoption on nonGAAP reporting. Available at SSRN: http://ssrn.com/abstract=20160516.

Laux, V. 2014. Pay convexity, earnings manipulation, and project continuation. The Accounting Review 89 (6), 2233-2259.

Laux, C, Laux, V., 2009. Board committees, CEO compensation, and earnings management. The Accounting Review 84 (3), 869-891.

Leuz, C., Verrecchia, R.E., 2000. The economic consequences of increased disclosure. Journal of Accounting Research 38, 91-124.

Lo, A.K., 2015. Accounting Credibility and Liquidity Constraints: Evidence from Reactions of Small Banks to Monetary Tightening. The Accounting Review 90 (3), 1079-1113.

McNichols, M.F., Stubben, S., 2008. Does earnings management affect firms' investment decisions? The Accounting Review 83 (6), 1571-1603.

Pyzoha, J.S. 2015. Why do restatements decrease in a clawback environment? An investigation into financial reporting executives' decision-making during the restatement process. The Accounting Review 90 (6), 2515-2536.

Roychowdhury, S. 2006. Earnings management through real activities manipulation. Journal of Accounting and Economics 42 (3), 335-370.

Securities and Exchange Commission, 2015. Proposed Rules Designed to Improve Quality of Financial Reporting and Enhance Accountability Benefitting Investors, File Number S7-1215 [Rule 10D-1]. Washington, DC: GPO.

Skinner, D.J., Sloan, R.G., 2002. Earnings surprises, growth expectations, and stock returns or don't let an earnings torpedo sink your portfolio. Review of Accounting Studies 7 (2), 289312.

U.S. House of Representatives, 2002. The Sarbanes-Oxley Act [Pub. L. 107-204]. Washington, DC: GPO.

U.S. House of Representatives, 2010. The Dodd-Frank Wall Street Reform and Consumer Protection Act [Pub. L. 111-203, H.R. 4173]. Washington, DC: GPO. 
Table 1

Sample selection and composition

Panel A. Clawback adopters by year

Compensation clawback adopters by year (excluding financial firms).

\begin{tabular}{ccc}
\hline Year & Number of new adopters & Total number of adopters \\
\hline 2005 & 19 & 19 \\
2006 & 73 & 92 \\
2007 & 108 & 200 \\
2008 & 136 & 336 \\
2009 & 108 & 444 \\
2010 & 221 & 665 \\
2011 & 158 & 823 \\
2012 & 209 & 1,032 \\
\hline
\end{tabular}

Panel B. Sample selection

Number of

observations

Clawback adopters (excluding financial firms) between 2005 and 2012

1,032

Matched with control firms using the propensity score matching

966

With financial and corporate governance data available between 2002 and 2012

9,500

Omitting observations beyond $T-3$ to $T+3$

$\underline{(5,300)}$

Final firm-year sample (between 2002 and 2012) (Panel B of Table 2)

$\underline{4,200^{1)}}$

Matched with Execucomp and missing values for control variables for expected compensation

Final firm-year sample (between 2002 and 2012) (Panel A of Table 2)

Note: 1) 4,200 observations for 892 firms (2,188 observations for 463 clawback adopters and 2,012 observations for 429 non-adopters), 2) 3,111 observations for 669 firms (1,674 observations for 357 clawback adopters and 1,437 observations for 312 non-adopters). 
Table 2

Summary statistics

Descriptive statistics for regression variables for clawback adopters and control firms based on propensity-score matching. All variables are defined in Appendix Table A1.

Panel A. CEO Compensation regression variables (3,111 observations)

\begin{tabular}{lcccccccc}
\hline & \multicolumn{3}{c}{ Clawback adopters } & \multicolumn{3}{c}{ Non-adopters } & \multicolumn{2}{c}{$\begin{array}{c}p \text {-value for } \\
\text { difference in }\end{array}$} \\
\cline { 2 - 9 } & Mean & Stdev & Median & Mean & Stddev & Median & $\begin{array}{c}\text { Mean } \\
(t \text {-test) }\end{array}$ & $\begin{array}{c}\text { Median } \\
\text { (Wilcoxon) }\end{array}$ \\
\hline TotalPay & 1.504 & 0.657 & 1.455 & 1.489 & 0.649 & 1.479 & 0.015 & -0.024 \\
EquityGrant & 1.015 & 0.716 & 0.964 & 1.002 & 0.717 & 0.956 & 0.013 & 0.008 \\
CashPay & 0.626 & 0.340 & 0.534 & 0.636 & 0.354 & 0.560 & -0.010 & $-0.026^{* * *}$ \\
ROA & 0.058 & 0.085 & 0.060 & 0.061 & 0.093 & 0.059 & -0.002 & 0.001 \\
RET & 0.113 & 0.459 & 0.064 & 0.139 & 0.457 & 0.091 & -0.026 & $-0.027^{* *}$ \\
VOLROA & 0.056 & 0.070 & 0.031 & 0.054 & 0.069 & 0.030 & 0.002 & 0.001 \\
VOLRET & 0.115 & 0.051 & 0.104 & 0.116 & 0.051 & 0.105 & -0.002 & 0.000 \\
MTB & 2.109 & 1.231 & 1.728 & 2.190 & 1.304 & 1.774 & $-0.081^{*}$ & -0.046 \\
LOGSALE & 7.725 & 1.411 & 7.608 & 7.677 & 1.499 & 7.620 & 0.048 & -0.012 \\
StockGrantRatio & 24.37 & 23.87 & 21.39 & 23.04 & 24.20 & 18.35 & 1.33 & $3.04^{*}$ \\
OptionGrantRati & 22.61 & 23.09 & 18.51 & 23.73 & 24.76 & 18.63 & -1.12 & -0.13 \\
o & & & & & & & & \\
SalaryRatio & 24.07 & 17.32 & 18.71 & 24.85 & 19.65 & 18.74 & -0.78 & -0.03 \\
RiskTolerance ${ }^{l)}$ & 28.12 & 16.93 & 29.66 & 25.61 & 16.69 & 25.98 & $2.51^{* * *}$ & $3.68^{* * * *}$ \\
\hline
\end{tabular}


Panel B. Investment regression variables (4,200 observations)

\begin{tabular}{|c|c|c|c|c|c|c|c|c|}
\hline & \multicolumn{3}{|c|}{ Clawback adopters } & \multicolumn{3}{|c|}{ Non-adopters } & \multicolumn{2}{|c|}{$\begin{array}{l}p \text {-value for } \\
\text { difference in }\end{array}$} \\
\hline & Mean & Stdev & Median & Mean & Stddev & Median & $\begin{array}{l}\text { Mean } \\
(t \text {-test }) \\
\end{array}$ & $\begin{array}{c}\text { Median } \\
\text { (Wilcoxon) }\end{array}$ \\
\hline \multicolumn{9}{|c|}{ Investment variables } \\
\hline Investment & 12.34 & 11.89 & 8.580 & 13.06 & 13.32 & 8.582 & $0.067^{*}$ & 0.500 \\
\hline Acquisition & 3.072 & 7.538 & 0.041 & 3.555 & 8.798 & 0.007 & $0.057^{*}$ & 0.877 \\
\hline Capex & 5.628 & 6.072 & 3.636 & 5.747 & 6.170 & 3.836 & 0.530 & 0.444 \\
\hline$R \& D$ & 3.543 & 5.767 & 0.208 & 3.371 & 5.757 & 0.000 & 0.335 & $0.082^{*}$ \\
\hline AmpleCash & 0.080 & 0.271 & 0.000 & 0.121 & 0.326 & 0.000 & $<.0001^{* * *}$ & $0.000^{* * *}$ \\
\hline ShortCash & 0.099 & 0.299 & 0.000 & 0.106 & 0.308 & 0.000 & 0.444 & 0.443 \\
\hline HighPerfPay ${ }^{2)}$ & 0.531 & 0.499 & 1.000 & 0.475 & 0.499 & 0.000 & $0.001^{* * *}$ & $0.001^{* * *}$ \\
\hline High Growth & 0.538 & 0.499 & 1.000 & 0.521 & 0.500 & 1.000 & 0.269 & 0.269 \\
\hline Institutions & 0.691 & 0.305 & 0.787 & 0.686 & 0.301 & 0.777 & 0.620 & 0.216 \\
\hline Analysts & 12.01 & 9.381 & 10.00 & 11.24 & 8.868 & 9.000 & $0.006^{* * *}$ & $0.021^{* *}$ \\
\hline G-Score & 6.213 & 4.956 & 8.000 & 5.550 & 4.962 & 7.000 & $<.0001^{* * *}$ & $0.000^{* * *}$ \\
\hline G-Dummy & 0.343 & 0.475 & 0.000 & 0.400 & 0.490 & 0.000 & $0.000^{* * *}$ & $0.000^{* * *}$ \\
\hline$A Q$ & -0.049 & 0.041 & -0.038 & -0.050 & 0.040 & -0.040 & 0.777 & 0.395 \\
\hline SalesGrowth & 9.132 & 22.42 & 7.539 & 11.624 & 25.86 & 8.414 & $0.001^{* * *}$ & $0.029^{* *}$ \\
\hline LogAsset & 7.519 & 1.568 & 7.412 & 7.380 & 1.553 & 7.370 & $0.004^{* * *}$ & $0.037^{* *}$ \\
\hline Mkt-to-Book & 1.830 & 1.074 & 1.492 & 1.924 & 1.215 & 1.516 & $0.008^{* * *}$ & 0.231 \\
\hline$S t d-C F O$ & 0.046 & 0.040 & 0.034 & 0.048 & 0.042 & 0.037 & 0.187 & 0.102 \\
\hline Std-Sale & 0.134 & 0.125 & 0.097 & 0.142 & 0.130 & 0.102 & $0.047^{* *}$ & $0.055^{*}$ \\
\hline Std-Inv & 8.920 & 12.392 & 4.985 & 9.241 & 12.322 & 4.963 & 0.401 & 0.507 \\
\hline Z-score & -2.158 & 1.039 & -2.225 & -2.175 & 1.201 & -2.200 & 0.634 & 0.463 \\
\hline Tangibility & 0.537 & 0.367 & 0.440 & 0.538 & 0.376 & 0.450 & 0.955 & 0.619 \\
\hline K-Structure & 0.184 & 0.190 & 0.135 & 0.198 & 0.207 & 0.138 & $0.028^{* *}$ & 0.588 \\
\hline Ind-K-Structure & 0.172 & 0.120 & 0.140 & 0.185 & 0.131 & 0.151 & $0.001^{* * *}$ & $0.003^{* * *}$ \\
\hline Slack & 0.160 & 0.170 & 0.099 & 0.166 & 0.185 & 0.093 & 0.284 & 0.416 \\
\hline CFOsale & 0.117 & 0.189 & 0.109 & 0.114 & 0.206 & 0.110 & 0.567 & 0.629 \\
\hline Dividend & 0.531 & 0.499 & 1.000 & 0.479 & 0.500 & 0.000 & $0.001^{* * *}$ & $0.001^{* * *}$ \\
\hline OperCycle & 4.562 & 0.698 & 4.672 & 4.527 & 0.684 & 4.588 & 0.104 & $0.026^{* *}$ \\
\hline Losses & 0.188 & 0.391 & 0.000 & 0.202 & 0.402 & 0.000 & 0.238 & 0.238 \\
\hline Age & 25.06 & 19.69 & 18.00 & 22.71 & 18.49 & 16.00 & $<.0001^{* * *}$ & $0.000^{* * *}$ \\
\hline
\end{tabular}

Note: 1) 2,973 observations due to missing values for Vega and Delta, 2) 3,335 observations due to missing values for CEO annual salary and total pay data 
Table 3

Effects of clawback adoptions on managerial incentives

Panel A. The sensitivity of CEO annual pay to accounting profitability

\begin{tabular}{|c|c|c|c|}
\hline & \multicolumn{3}{|c|}{ Dependent Variable (AnnualPay) } \\
\hline & $\begin{array}{c}\text { TotalPay } \\
\text { (1) }\end{array}$ & $\begin{array}{c}\text { EquityGrant } \\
\text { (2) }\end{array}$ & $\begin{array}{c}\text { CashPay } \\
\text { (3) }\end{array}$ \\
\hline Post & $\begin{array}{l}0.140 \\
(0.92)\end{array}$ & $\begin{array}{l}0.006 \\
(0.03)\end{array}$ & $\begin{array}{l}0.337 \\
(4.32)\end{array}$ \\
\hline Clawback $*$ Post & $\begin{array}{l}-0.100 \\
(-0.47)\end{array}$ & $\begin{array}{l}0.174 \\
(0.62)\end{array}$ & $\begin{array}{l}-0.018 \\
(-0.16)\end{array}$ \\
\hline$R O A$ & $\begin{array}{l}0.608^{* * * *} \\
(3.16)\end{array}$ & $\begin{array}{l}0.458 \text { * } \\
(1.80)\end{array}$ & $\begin{array}{l}0.202^{* *} \\
(2.04)\end{array}$ \\
\hline Clawback*ROA & $\begin{array}{l}-0.290 \\
(-1.08)\end{array}$ & $\begin{array}{l}-0.611 \\
(-1.72)\end{array}$ & $\begin{array}{l}-0.055 \\
(-0.40)\end{array}$ \\
\hline Post*ROA & $\begin{array}{l}-0.287 \\
(-1.11)\end{array}$ & $\begin{array}{l}-0.5644^{*} \\
(-1.64)\end{array}$ & $\begin{array}{l}0.071 \\
(0.53)\end{array}$ \\
\hline Clawback*Post*ROA & $\begin{array}{l}\mathbf{0 . 8 5 4} 4^{* *} \\
(2.25)\end{array}$ & $\begin{array}{l}1.169 \\
(2.33)\end{array}$ & $\begin{array}{l}-0.182 \\
(-0.94)\end{array}$ \\
\hline Control variables & & & \\
\hline$R E T$ & $\begin{array}{l}0.090^{* * * *} \\
(2.72)\end{array}$ & $\begin{array}{l}0.030 \\
(0.68)\end{array}$ & $\begin{array}{l}0.026 \\
(1.50)\end{array}$ \\
\hline VOLROA & $\begin{array}{l}0.595^{*} \\
(1.71)\end{array}$ & $\begin{array}{l}0.145 \\
(0.31)\end{array}$ & $\begin{array}{l}0.166 \\
(0.93)\end{array}$ \\
\hline VOLRET & $\begin{array}{l}0.780 \\
(1.60)\end{array}$ & $\begin{array}{l}1.335^{* *} \\
(2.06)\end{array}$ & $\begin{array}{l}-0.120 \\
(-0.48)\end{array}$ \\
\hline$M T B$ & $\begin{array}{l}-0.054^{* *} \\
(-1.96)\end{array}$ & $\begin{array}{l}-0.024 \\
(-0.66)\end{array}$ & $\begin{array}{l}-0.007 \\
(-0.52)\end{array}$ \\
\hline LOGSALE & $\begin{array}{l}0.229^{* * *} \\
(4.41)\end{array}$ & $\begin{array}{l}0.145^{\text {** }} \\
(2.11)\end{array}$ & $\begin{array}{l}0.132^{* * *} \\
(4.95)\end{array}$ \\
\hline Clawback*RET & $\begin{array}{l}-0.021 \\
(-0.49)\end{array}$ & $\begin{array}{l}0.014 \\
(0.25)\end{array}$ & $\begin{array}{l}0.005 \\
(0.23)\end{array}$ \\
\hline Clawback*VOLROA & $\begin{array}{l}-1.037^{* *} \\
(-2.21)\end{array}$ & $\begin{array}{l}-0.509 \\
(-0.82)\end{array}$ & $\begin{array}{l}-0.166 \\
(-0.69)\end{array}$ \\
\hline Clawback*VOLRET & $\begin{array}{l}-0.975 \\
(-1.60)\end{array}$ & $\begin{array}{l}-1.429 \\
(-1.78)\end{array}$ & $\begin{array}{l}0.436 \\
(1.39)\end{array}$ \\
\hline Clawback*MTB & $\begin{array}{l}0.132^{\text {**** }} \\
(3.77)\end{array}$ & $\begin{array}{l}0.166^{* * *} \\
(3.59)\end{array}$ & $\begin{array}{l}-0.016 \\
(-0.89)\end{array}$ \\
\hline Clawback*LOGSALE & $\begin{array}{l}-0.003 \\
(-0.03)\end{array}$ & $\begin{array}{l}0.066 \\
(0.68)\end{array}$ & $\begin{array}{l}-0.062 \\
(-1.65)\end{array}$ \\
\hline$P O S T^{*} R E T$ & $\begin{array}{l}-0.005 \\
(-0.12)\end{array}$ & $\begin{array}{l}-0.004 \\
(-0.08)\end{array}$ & $\begin{array}{l}-0.007 \\
(-0.32)\end{array}$ \\
\hline$P O S T * V O L R O A$ & $-0.831^{* *}$ & -0.551 & -0.142 \\
\hline
\end{tabular}




\begin{tabular}{|c|c|c|c|}
\hline & $(-2.13)$ & $(-1.07)$ & $(-0.71)$ \\
\hline \multirow[t]{2}{*}{ POST*VOLRET } & -0.472 & $-1.121^{*}$ & 0.324 \\
\hline & $(-0.92)$ & $(-1.66)$ & $(1.23)$ \\
\hline \multirow[t]{2}{*}{$P O S T^{*} M T B$} & 0.019 & 0.029 & -0.013 \\
\hline & $(0.95)$ & $(1.11)$ & $(-1.32)$ \\
\hline \multirow[t]{2}{*}{$P O S T * L O G S A L E$} & -0.010 & 0.016 & $-0.044^{* * *}$ \\
\hline & $(-0.71)$ & $(0.85)$ & $(-5.92)$ \\
\hline \multirow[t]{2}{*}{ Clawback*Post*RET } & 0.005 & -0.068 & -0.007 \\
\hline & $(0.08)$ & $(-0.84)$ & $(-0.21)$ \\
\hline \multirow[t]{2}{*}{ Clawback* Post*VOLROA } & 0.510 & 0.039 & 0.243 \\
\hline & $(1.00)$ & $(0.06)$ & $(0.92)$ \\
\hline \multirow[t]{2}{*}{ Clawback*Post*VOLRET } & 0.650 & 1.232 & -0.536 \\
\hline & $(0.94)$ & $(1.35)$ & $(-1.51)$ \\
\hline \multirow[t]{2}{*}{ Clawback*Post*MTB } & $-0.062^{* *}$ & $-0.092^{* *}$ & -0.004 \\
\hline & $(-2.14)$ & $(-2.41)$ & $(-0.25)$ \\
\hline \multirow[t]{2}{*}{ Clawback*Post*LOGSALE } & 0.009 & -0.027 & 0.007 \\
\hline & $(0.46)$ & $(-1.02)$ & $(0.72)$ \\
\hline Firm-fixed effects & Yes & Yes & Yes \\
\hline Year-fixed effects & Yes & Yes & Yes \\
\hline Overall $\mathrm{R}^{2}$ & 0.412 & 0.132 & 0.175 \\
\hline$N$ & 3,111 & 3,111 & 3,111 \\
\hline
\end{tabular}


Panel B. The composition of CEO annual total pay and the sensitivity of CEO equity portfolio value to stock price changes

\begin{tabular}{|c|c|c|c|c|}
\hline & \multicolumn{4}{|c|}{ Dependent variable } \\
\hline & $\begin{array}{c}\text { StockGrantRatio } \\
\text { (1) }\end{array}$ & $\begin{array}{c}\text { OptionGrantRatio } \\
\text { (2) }\end{array}$ & $\begin{array}{l}\text { SalaryRatio } \\
\text { (3) }\end{array}$ & $\begin{array}{c}\text { RiskTolerance } \\
\text { (4) }\end{array}$ \\
\hline \multirow[t]{2}{*}{ Post } & -1.612 & 2.258 & 0.071 & 0.465 \\
\hline & $(-1.09)$ & (1.62) & $(0.06)$ & $(0.54)$ \\
\hline \multirow[t]{2}{*}{ Clawback*Post } & 1.845 & $-2.692^{* * *}$ & 0.615 & $-1.974^{* *}$ \\
\hline & $(1.36)$ & $(-2.10)$ & $(0.59)$ & $(-2.46)$ \\
\hline \multicolumn{5}{|l|}{ Control variables } \\
\hline \multirow[t]{2}{*}{$R O A$} & 0.938 & $-19.22^{* * *}$ & $-15.782^{* * *}$ & $-13.726^{* * *}$ \\
\hline & $(0.16)$ & $(-3.57)$ & $(-3.62)$ & $(-4.09)$ \\
\hline \multirow[t]{2}{*}{$R E T$} & $-1.571^{*}$ & -0.092 & $-3.734^{* * *}$ & $-6.137^{* * *}$ \\
\hline & $(-1.71)$ & $(-1.06)$ & $(-5.32)$ & $(-11.45)$ \\
\hline \multirow[t]{2}{*}{ VOLROA } & $-25.83^{* *}$ & 8.587 & 1.003 & 2.285 \\
\hline & $(-2.27)$ & $(0.80)$ & $(0.12)$ & $(0.34)$ \\
\hline \multirow[t]{2}{*}{ VOLRET } & $-45.59^{* * *}$ & $54.816^{* * *}$ & -7.792 & -7.058 \\
\hline & $(-2.84)$ & (3.62) & $(-0.64)$ & $(-0.75)$ \\
\hline \multirow[t]{2}{*}{$M T B$} & -1.132 & $5.222^{* * * *}$ & -0.413 & $-2.316^{* * *}$ \\
\hline & $(-1.26)$ & $(6.19)$ & $(-0.60)$ & $(-4.40)$ \\
\hline \multirow[t]{2}{*}{ LOGSALE } & -0.688 & 0.696 & $-4.325^{* * *}$ & 0.175 \\
\hline & $(-0.36)$ & $(0.38)$ & $(-2.94)$ & $(0.15)$ \\
\hline Firm-fixed effects & Yes & Yes & Yes & Yes \\
\hline Year-fixed effects & Yes & Yes & Yes & Yes \\
\hline Overall $\mathrm{R}^{2}$ & 0.054 & 0.085 & 0.140 & 0.064 \\
\hline $\mathrm{N}$ & 3,111 & 3,111 & 3,111 & 2,973 \\
\hline
\end{tabular}

Note: See Appendix Table A1 for variable definitions. Panels A and B show results of running OLS regression for Equations 2 and 3 with firm- and year-fixed effects, respectively. T-statistics are reported in parentheses. $* * *$, and $* * *$ represent significance at the $10 \%, 5 \%$, and $1 \%$ level in a two-tailed test, respectively. Overall $\mathrm{R}^{2}$ means a weighted average of the between R-squared and the within R-squared. Column (4) of Panel B uses 2,973 observations due to missing values for Vega and Delta. 
Table 4

Effects of clawback adoptions on managerial incentives for subsamples for high versus low performance-based pay partitions

Panel A. The sensitivity of CEO annual pay to accounting profitability

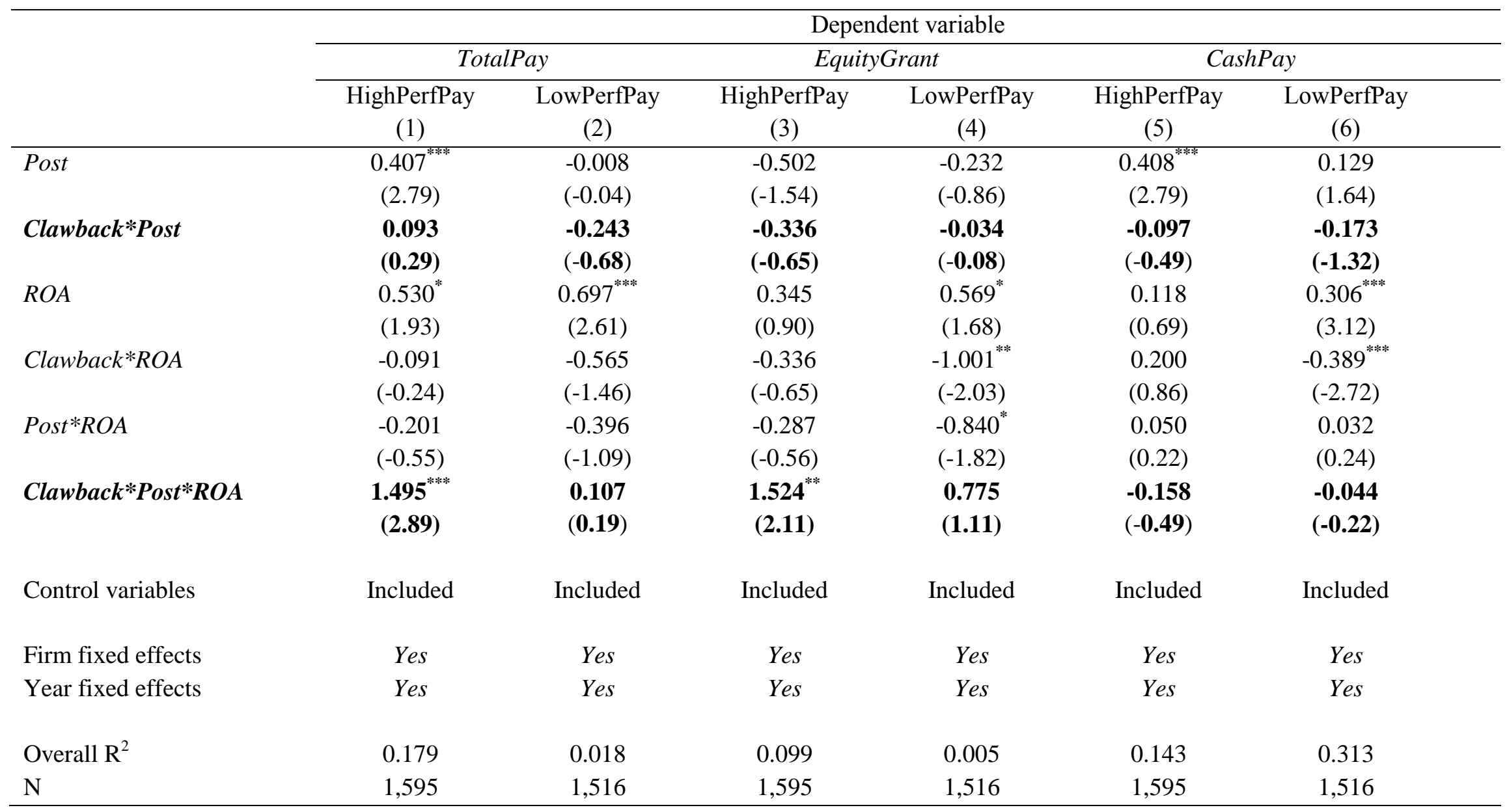


Panel B. The composition of CEO annual total pay and the sensitivity of CEO equity portfolio value to stock price changes

\begin{tabular}{|c|c|c|c|c|c|c|c|c|}
\hline & \multicolumn{8}{|c|}{ Dependent variable } \\
\hline & \multicolumn{2}{|c|}{ StockgrantRatio } & \multicolumn{2}{|c|}{ OptiongrantRatio } & \multicolumn{2}{|c|}{ SalaryRatio } & \multicolumn{2}{|c|}{ RiskTolerance } \\
\hline & $\begin{array}{l}\text { HighPerfPay } \\
\text { (1) }\end{array}$ & $\begin{array}{c}\text { LowPerfPay } \\
\text { (2) }\end{array}$ & $\begin{array}{l}\text { HighPerfPay } \\
\text { (3) }\end{array}$ & $\begin{array}{c}\text { LowPerfPay } \\
\text { (4) }\end{array}$ & $\begin{array}{l}\text { HighPerfPay } \\
\text { (5) }\end{array}$ & $\begin{array}{c}\text { LowPerfPay } \\
\text { (6) }\end{array}$ & $\begin{array}{c}\text { HighPerfPay } \\
\text { (7) }\end{array}$ & $\begin{array}{c}\text { LowPerfPay } \\
\text { (8) }\end{array}$ \\
\hline Post & $-3.918^{*}$ & 0.617 & 1.310 & 2.757 & $2.358^{* * * *}$ & -1.651 & 0.732 & 0.047 \\
\hline & $(-1.93)$ & $(0.29)$ & $(0.71)$ & (1.33) & $(2.87)$ & $(-0.79)$ & $(0.61)$ & $(0.04)$ \\
\hline Clawback*Post & 0.345 & 1.388 & $-2.860^{*}$ & -1.564 & -0.541 & 1.044 & $-2.977^{* * *}$ & -0.765 \\
\hline & $(\mathbf{0 . 3 7})$ & $(0.69)$ & $(-1.69)$ & $(-\mathbf{0 . 8 0})$ & $(-0.72)$ & $(\mathbf{0 . 5 3})$ & $(-2.71)$ & $(-0.65)$ \\
\hline Control variables & Included & Included & Included & Included & Included & Included & Included & Included \\
\hline Firm fixed effects & Yes & Yes & Yes & Yes & Yes & Yes & Yes & Yes \\
\hline Year fixed effects & Yes & Yes & Yes & Yes & Yes & Yes & Yes & Yes \\
\hline Overall $\mathrm{R}^{2}$ & 0.071 & 0.044 & 0.148 & 0.022 & 0.112 & 0.062 & 0.042 & 0.082 \\
\hline $\mathrm{N}$ & 1,595 & 1,516 & 1,595 & 1,516 & 1,595 & 1,516 & 1,549 & 1,424 \\
\hline
\end{tabular}

Note: See Appendix Table A1 for variable definitions. Panels A and B show results of running OLS regression Equations 2 and 3 with firmand year-fixed effects. Coefficients on control variables not reported for brevity. T-statistics are reported in parentheses. *, **, and *** represent significance at the $10 \%, 5 \%$, and $1 \%$ level in a two-tailed test, respectively. Overall $\mathrm{R}^{2}$ means a weighted average of the between $\mathrm{R}$-squared and the within R-squared. 
Table 5

Effects of clawback adoptions on next-period capital investment by type

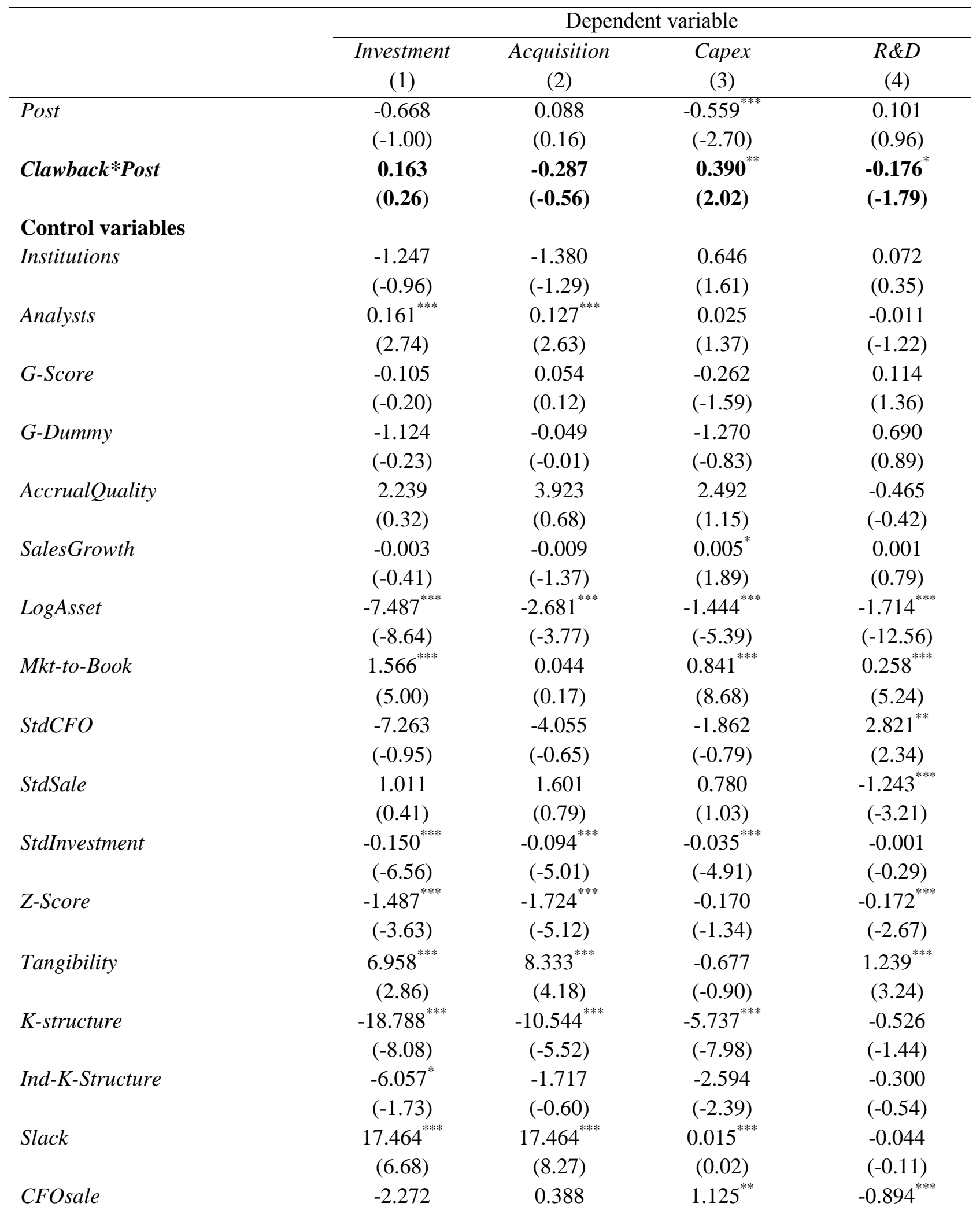




\begin{tabular}{lcccc} 
& $(-1.57)$ & $(0.33)$ & $(2.51)$ & $(-3.91)$ \\
Dividend & -0.524 & 0.049 & -0.329 & -0.218 \\
& $(-0.59)$ & $(0.07)$ & $(-1.20)$ & $(-1.52)$ \\
OperatingCycle & 0.437 & 0.379 & 0.204 & $0.638^{* * *}$ \\
& $(0.61)$ & $(0.64)$ & $(0.92)$ & $(5.65)$ \\
Losses & -0.531 & -0.564 & 0.138 & $0.252^{* * *}$ \\
& $(-0.92)$ & $(-1.19)$ & $(0.77)$ & $(2.77)$ \\
Age & 0.009 & -0.050 & 0.028 & 0.018 \\
& $(-0.92)$ & $(-0.12)$ & $(0.18)$ & $(0.23)$ \\
Firm-fixed effects & & & & Yes \\
Year-fixed effects & Yes & Yes & Yes & Yes \\
Yes & Yes & & 0.090 \\
Overall R & & & 0.000 & 4,200 \\
\hline
\end{tabular}

Note: See Appendix Table A1 for variable definitions. Estimated using OLS regression for Equation 4 with firm- and year-fixed effects. T-statistics are reported in parentheses. ${ }^{*}, * *$, and $* * *$ represent significance at the $10 \%, 5 \%$, and $1 \%$ level in a two-tailed test, respectively. Overall $\mathrm{R}^{2}$ means a weighted average of the between R-squared and the within R-squared. 
Table 6

Effects of clawback adoptions on next-period capital investment by type for high versus low performance-based pay partitions

\begin{tabular}{|c|c|c|c|c|c|c|c|c|}
\hline & \multicolumn{8}{|c|}{ Dependent variable } \\
\hline & \multicolumn{2}{|c|}{ Investment } & \multicolumn{2}{|c|}{ Acquisition } & \multicolumn{2}{|c|}{ Capex } & \multicolumn{2}{|c|}{$R \& D$} \\
\hline & $\begin{array}{l}\text { HighPerfPay } \\
\text { (1) }\end{array}$ & $\begin{array}{c}\text { LowPerfPay } \\
\text { (2) }\end{array}$ & $\begin{array}{l}\text { HighPerfPay } \\
\text { (3) }\end{array}$ & $\begin{array}{c}\text { LowPerfPay } \\
\text { (4) }\end{array}$ & $\begin{array}{l}\text { HighPerfPay } \\
\text { (5) }\end{array}$ & $\begin{array}{c}\text { LowPerfPay } \\
\text { (6) }\end{array}$ & $\begin{array}{c}\text { HighPerfPay } \\
\text { (7) }\end{array}$ & $\begin{array}{c}\text { LowPerfPay } \\
\text { (8) }\end{array}$ \\
\hline \multirow[t]{2}{*}{ Post } & -0.602 & -0.627 & 0.011 & -0.243 & -0.820 & 0.029 & 0.174 & -0.162 \\
\hline & $(-0.58)$ & $(-0.56)$ & $(0.01)$ & $(-0.25)$ & $(-3.04)$ & $(0.09)$ & $(1.05)$ & $(-1.04)$ \\
\hline \multirow[t]{2}{*}{ Clawback*Post } & 0.071 & -0.582 & -0.502 & -0.489 & $0.982^{* * *}$ & -0.315 & $-0.276^{*}$ & 0.102 \\
\hline & $(0.07)$ & $(-0.54)$ & $(-0.62)$ & $(-0.53)$ & (3.93) & $(-1.02)$ & $(-1.80)$ & $(0.68)$ \\
\hline \multirow[t]{2}{*}{ RiskTolerance } & 0.009 & $-0.555^{*}$ & -0.015 & -0.031 & $0.012^{*}$ & $-0.024^{*}$ & 0.002 & 0.004 \\
\hline & $(0.34)$ & $(-1.94)$ & $(-0.68)$ & $(-1.27)$ & $(1.73)$ & $(-2.95)$ & $(0.48)$ & (1.10) \\
\hline $\begin{array}{l}\text { Other control } \\
\text { variables }\end{array}$ & Included & Included & Included & Included & Included & Included & Included & Included \\
\hline $\begin{array}{l}\text { Firm fixed } \\
\text { effects }\end{array}$ & Yes & Yes & Yes & Yes & Yes & Yes & Yes & Yes \\
\hline $\begin{array}{l}\text { Year fixed } \\
\text { effects }\end{array}$ & Yes & Yes & Yes & Yes & Yes & Yes & Yes & Yes \\
\hline Overall $\mathrm{R}^{2}$ & 0.062 & 0.001 & 0.012 & 0.001 & 0.020 & 0.007 & 0.026 & 0.022 \\
\hline $\mathrm{N}$ & 1,581 & 1,474 & 1,581 & 1,474 & 1,581 & 1,474 & 1,581 & 1,474 \\
\hline
\end{tabular}

Note: See Appendix Table A1 for variable definitions. Estimated using OLS regression for Equation 4 with firm- and year-fixed effects. Coefficients on control variables not reported for brevity. T-statistics are reported in parentheses. *, **, and *** represent significance at the $10 \%, 5 \%$, and $1 \%$ level in a two-tailed test, respectively. Overall $\mathrm{R}^{2}$ means a weighted average of the between $\mathrm{R}$-squared and the within $\mathrm{R}-$ squared. 
Table 7

Effect of clawback adoptions on deviations from expected capital investments by type

Panel A. Total sample

\begin{tabular}{|c|c|c|c|c|}
\hline & \multicolumn{4}{|c|}{ Dependent variable $=$ Overinvesting (versus Benchmark) } \\
\hline & $\begin{array}{c}\text { Investment } \\
\text { (1) }\end{array}$ & $\begin{array}{c}\text { Acquisition } \\
\text { (2) }\end{array}$ & $\begin{array}{l}\text { Capex } \\
\text { (3) }\end{array}$ & $\begin{array}{c}R \& D \\
(4)\end{array}$ \\
\hline Clawback & $\begin{array}{l}-0.205^{*} \\
(-1.86)\end{array}$ & $\begin{array}{l}-0.066 \\
(-0.64)\end{array}$ & $\begin{array}{l}-0.122 \\
(-1.08)\end{array}$ & $\begin{array}{l}-0.003 \\
(-0.02)\end{array}$ \\
\hline Post & $\begin{array}{c}-0.369^{* * *} \\
(-2.71)\end{array}$ & $\begin{array}{l}-0.099 \\
(-0.83)\end{array}$ & $\begin{array}{l}-0.263^{*} \\
(-1.91)\end{array}$ & $\begin{array}{l}-0.130 \\
(-0.76)\end{array}$ \\
\hline Clawback*Post & $\begin{array}{l}0.254 \\
(1.44)\end{array}$ & $\begin{array}{l}0.086 \\
(0.56)\end{array}$ & $\begin{array}{l}0.336{ }^{*} \\
(1.88)\end{array}$ & $\begin{array}{l}0.243 \\
(1.13)\end{array}$ \\
\hline Control variables & Included & Included & Included & Included \\
\hline Industry fixed effects & Yes & Yes & Yes & Yes \\
\hline Year fixed effects & Yes & Yes & Yes & Yes \\
\hline Pseudo- $\mathrm{R}^{2}$ & 0.126 & 0.093 & 0.221 & 0.270 \\
\hline $\mathrm{N}$ & 3,233 & 3,371 & 3,336 & 2,728 \\
\hline
\end{tabular}


Panel B. High versus low performance-based pay partitions

\begin{tabular}{|c|c|c|c|c|c|c|c|c|}
\hline & \multicolumn{8}{|c|}{ Dependent variable $=$ Overinvesting (versus Benchmark) } \\
\hline & \multicolumn{2}{|c|}{ Investment } & \multicolumn{2}{|c|}{ Acquisition } & \multicolumn{2}{|c|}{ Capex } & \multicolumn{2}{|c|}{$R \& D$} \\
\hline & $\begin{array}{l}\text { HighPerfPay } \\
\text { (1) }\end{array}$ & $\begin{array}{c}\text { LowPerfPay } \\
\text { (2) }\end{array}$ & $\begin{array}{l}\text { HighPerfPay } \\
\text { (3) }\end{array}$ & $\begin{array}{c}\text { LowPerfPay } \\
\text { (4) }\end{array}$ & $\begin{array}{c}\text { HighPerfPay } \\
\text { (5) }\end{array}$ & $\begin{array}{c}\text { LowPerfPay } \\
\text { (6) }\end{array}$ & $\begin{array}{l}\text { HighPerfPay } \\
\text { (7) }\end{array}$ & $\begin{array}{c}\text { LowPerfPay } \\
\text { (8) }\end{array}$ \\
\hline \multirow[t]{2}{*}{ Clawback } & $-0.414^{\text {** }}$ & 0.015 & -0.031 & -0.125 & -0.199 & -0.196 & 0.084 & 0.216 \\
\hline & $(-2.03)$ & $(0.08)$ & $(-0.18)$ & $(-0.68)$ & $(-0.93)$ & $(-0.92)$ & $(0.31)$ & $(0.78)$ \\
\hline \multirow[t]{2}{*}{ Post } & $-0.686^{* *}$ & -0.197 & $-0.630^{* * *}$ & 0.168 & -0.174 & -0.307 & 0.188 & -0.218 \\
\hline & $(-2.66)$ & $(-0.84)$ & $(-2.97)$ & $(0.82)$ & $(-0.69)$ & $(-1.27)$ & $(0.57)$ & $(-0.65)$ \\
\hline \multirow[t]{2}{*}{ Clawback $*$ Post } & $0.676^{* *}$ & 0.030 & 0.351 & -0.102 & $0.553^{*}$ & 0.092 & 0.008 & 0.250 \\
\hline & $(2.12)$ & $(0.10)$ & (1.34) & $(-0.37)$ & (1.79) & $(0.28)$ & $(0.02)$ & $(\mathbf{0 . 5 8})$ \\
\hline \multirow[t]{2}{*}{ RiskTolerance } & 0.005 & -0.008 & -0.001 & $-0.013^{* * *}$ & 0.005 & 0.003 & $0.022^{\text {*** }}$ & $0.026^{* * * *}$ \\
\hline & $(0.85)$ & $(-1.50)$ & $(-0.30)$ & $(-2.80)$ & $(0.94)$ & $(0.47)$ & $(3.20)$ & $(3.48)$ \\
\hline $\begin{array}{l}\text { Other control } \\
\text { variables }\end{array}$ & Included & Included & Included & Included & Included & Included & Included & Included \\
\hline $\begin{array}{l}\text { Industry fixed } \\
\text { effects }\end{array}$ & Yes & Yes & Yes & Yes & Yes & Yes & Yes & Yes \\
\hline $\begin{array}{l}\text { Year fixed } \\
\text { effects }\end{array}$ & Yes & Yes & Yes & Yes & Yes & Yes & Yes & Yes \\
\hline Pseudo-R ${ }^{2}$ & 0.161 & 0.129 & 0.124 & 0.119 & 0.251 & 0.306 & 0.278 & 0.312 \\
\hline $\mathrm{N}$ & 1,151 & 1,116 & 1,269 & 1,193 & 1,190 & 1,212 & 905 & 740 \\
\hline
\end{tabular}

Note: Variables are defined in Appendix Table A1. Estimated using logistic regression for Equation 5 with year- and industry-fixed effects. Industry classification is based on two-digit SIC codes. Z-statistics are reported in parentheses. *, **, and *** represent significance at the $10 \%, 5 \%$, and $1 \%$ levels in a two-tailed test, respectively. Overall $\mathrm{R}^{2}$ means a weighted average of the between R-squared and the within $\mathrm{R}$-squared. 
Table 8

Effects of clawback adoptions on next-period capital investment by type and firm liquidity

\begin{tabular}{|c|c|c|c|c|}
\hline & \multicolumn{4}{|c|}{ Dependent variable } \\
\hline & $\begin{array}{c}\text { Investment } \\
\text { (1) }\end{array}$ & $\begin{array}{l}\text { Acquisition } \\
\text { (2) }\end{array}$ & $\begin{array}{l}\text { Capex } \\
\text { (3) }\end{array}$ & $\begin{array}{c}R \& D \\
(4)\end{array}$ \\
\hline Post & $\begin{array}{l}-0.934 \\
(-1.27)\end{array}$ & $\begin{array}{l}-0.158 \\
(-0.39)\end{array}$ & $\begin{array}{c}-1.122^{3} \\
(-2.42)\end{array}$ & $\begin{array}{l}0.089 \\
(0.58)\end{array}$ \\
\hline Clawback*Post & $\begin{array}{l}0.189 \\
(0.26)\end{array}$ & $\begin{array}{l}-0.521 \\
(-1.33)\end{array}$ & $\begin{array}{l}1.028^{* *} \\
(2.27)\end{array}$ & $\begin{array}{l}-0.222 \\
(-1.48)\end{array}$ \\
\hline Conditioning variables & & & & \\
\hline Post*AmpleCash & $\begin{array}{c}3.015^{* *} \\
(2.07)\end{array}$ & $\begin{array}{l}1.039 \\
(1.31)\end{array}$ & $\begin{array}{l}-0.071 \\
(-0.08)\end{array}$ & $\begin{array}{l}-0.012 \\
(-0.04)\end{array}$ \\
\hline Clawback*Post*AmpleCash & $\begin{array}{l}1.161 \\
(0.53)\end{array}$ & $\begin{array}{l}2.440^{* *} \\
(2.02)\end{array}$ & $\begin{array}{l}-1.436 \\
(-1.03)\end{array}$ & $\begin{array}{l}0.163 \\
(0.35)\end{array}$ \\
\hline Post $*$ ShortCash & $\begin{array}{l}-0.127 \\
(-0.08)\end{array}$ & $\begin{array}{l}-0.157 \\
(-0.18)\end{array}$ & $\begin{array}{l}1.006 \\
(1.01)\end{array}$ & $\begin{array}{l}-0.083 \\
(-0.25)\end{array}$ \\
\hline Clawback* Post ${ }^{*}$ ShortCash & $\begin{array}{l}-1.299 \\
(-0.61)\end{array}$ & $\begin{array}{l}-0.562 \\
(-0.48)\end{array}$ & $\begin{array}{l}-0.485 \\
(-0.36)\end{array}$ & $\begin{array}{l}-0.216 \\
(-0.48)\end{array}$ \\
\hline Control variables & Included & Included & Included & Included \\
\hline Firm fixed effects & Yes & Yes & Yes & Yes \\
\hline Year fixed effects & Yes & Yes & Yes & Yes \\
\hline Overall $\mathrm{R}^{2}$ & 0.081 & 0.011 & 0.166 & 0.109 \\
\hline $\mathrm{N}$ & 4,200 & 4,200 & 4,200 & 4,200 \\
\hline
\end{tabular}

Note: See Appendix Table A1 for variable definitions. Estimated using OLS regression for Equation 5 with interactions with the indicator variables for ample and short liquidity and with firm- and year-fixed effects. Coefficients on control variables not reported for brevity. T-statistics are reported in parentheses. *, **, and $* * *$ represent significance at the $10 \%, 5 \%$, and $1 \%$ level in a two-tailed test, respectively. Overall $\mathrm{R}^{2}$ means a weighted average of the between R-squared and the within R-squared. 
Table 9

Effects of clawback adoptions on next-period capital investment by type for market-perceived growth opportunities

\begin{tabular}{|c|c|c|c|c|c|c|c|c|}
\hline & \multicolumn{8}{|c|}{ Dependent variable } \\
\hline & \multicolumn{2}{|c|}{ Investment } & \multicolumn{2}{|c|}{ Acquisition } & \multicolumn{2}{|c|}{ Capex } & \multicolumn{2}{|c|}{$R \& D$} \\
\hline & $\begin{array}{l}\text { High Growth } \\
\text { (1) }\end{array}$ & $\begin{array}{c}\text { Low Growth } \\
\text { (2) }\end{array}$ & $\begin{array}{l}\text { High Growth } \\
\text { (3) }\end{array}$ & $\begin{array}{c}\text { Low Growth } \\
\text { (4) }\end{array}$ & $\begin{array}{l}\text { High Growth } \\
\text { (5) }\end{array}$ & $\begin{array}{c}\text { Low Growth } \\
\text { (6) }\end{array}$ & $\begin{array}{l}\text { High Growth } \\
\text { (7) }\end{array}$ & $\begin{array}{c}\text { Low Growth } \\
\text { (8) }\end{array}$ \\
\hline Post & $\begin{array}{l}-0.685 \\
(-0.73)\end{array}$ & $\begin{array}{l}-0.941 \\
(-0.99)\end{array}$ & $\begin{array}{l}-0.171 \\
(-0.22)\end{array}$ & $\begin{array}{l}0.399 \\
(0.51)\end{array}$ & $\begin{array}{l}-0.489^{*} \\
(-1.89)\end{array}$ & $\begin{array}{l}-0.602^{*} \\
(-1.78)\end{array}$ & $\begin{array}{l}0.116 \\
(0.72)\end{array}$ & $\begin{array}{l}0.010 \\
(0.09)\end{array}$ \\
\hline Clawback*Post & $\begin{array}{l}-0.105 \\
(-0.12)\end{array}$ & $\begin{array}{l}0.615 \\
(0.68)\end{array}$ & $\begin{array}{c}-0.111 \\
(-0.16)\end{array}$ & $\begin{array}{c}-0.433 \\
(-0.59)\end{array}$ & $\begin{array}{l}0.474^{* *} \\
(1.98)\end{array}$ & $\begin{array}{r}0.253 \\
(0.79)\end{array}$ & $\begin{array}{l}-0.432^{\text {**** }} \\
(-2.91)\end{array}$ & $\begin{array}{l}0.160 \\
(1.41)\end{array}$ \\
\hline Control variables & Included & Included & Included & Included & Included & Included & Included & Included \\
\hline Firm fixed effects & Yes & Yes & Yes & Yes & Yes & Yes & Yes & Yes \\
\hline Year fixed effects & Yes & Yes & Yes & Yes & Yes & Yes & Yes & Yes \\
\hline Overall $\mathrm{R}^{2}$ & 0.045 & 0.077 & 0.001 & 0.019 & 0.000 & 0.003 & 0.052 & 0.230 \\
\hline $\mathrm{N}$ & 2,284 & 1,913 & 2,284 & 1,913 & 2,284 & 1,913 & 2,284 & 1,913 \\
\hline
\end{tabular}

Note: See Appendix Table A1 for variable definitions. Estimated using OLS regression for Equation 5 with firm- and year-fixed effects. Coefficients on control variables not reported for brevity. T-statistics are reported in parentheses. $*$, **, and $* * *$ represent significance at the $10 \%$, $5 \%$, and $1 \%$ level in a two-tailed test, respectively. Overall $\mathrm{R}^{2}$ means a weighted average of the between R-squared and the within $\mathrm{R}$-squared. 
Table A1

Variable definitions

Clawback $\quad 1$ if a firm is in the treatment group (clawback adopters) and 0 if a firm is instead in the control group (non-adopters)

Post 1 for all firm-years (including clawback and control firms) if clawback provisions are in place in a year, and 0 otherwise

Clawback* Post 1 for all firm-years for clawback firms if clawback provisions are in place in a year, and 0 otherwise

\section{Compensation regressions}

TotalPay The natural logarithm of one plus inflation-adjusted CEO annual total pay (ExecuComp $t d c 1$ ) for year $t$. Inflation adjustment is based on Consumer Price Index.

EquityGrant The natural logarithm of one plus inflation-adjusted CEO annual equity grants (i.e., option grants + stock grants) for year $t$. Inflation adjustment is based on CPI.

CashPay The natural logarithm of one plus inflation-adjusted CEO annual cash pay (ExecuComp totalcurr) for year $t$. Inflation adjustment is based on CPI.

$R O A \quad$ Accounting return on assets for year $t$ (net income before extraordinary items and discontinued operations deflated by lagged total assets)

RET One-year stock returns during year $t$

VOLROA The standard deviation of return on assets over the prior five years

VOLRET The standard deviation of stock returns over the prior five years

$M T B$

The firm's investment opportunity set with the firm's year-end market-to-book ratio averaged over the previous five years

LogSale The natural logarithm of sales revenue during year $t+1$

StockGrantRatio CEO annual stock grants times 100 divided by CEO annual total pay for year $t$

OptionGrantRatio CEO annual option grants times 100 divided by CEO annual total pay for year $t$

SalaryRatio $\quad$ CEO annual salary times 100 divided by CEO annual total pay for year $t$

RiskTolerance $^{l)} \quad$ Vega times 100 divided by the sum of Delta and Vega for year $t$

Delta The sensitivity of CEO stock and option portfolio value to stock returns

Vega The sensitivity of CEO stock and option portfolio value to stock return volatility

\section{Investment regressions}

Investment One-year-ahead net investment (capital expenditure - cash receipts from sale of property, plant, and equipment + acquisitions + research and development expenditure) multiplied by 100 and deflated by current-year total assets.

Acquisition One-year-ahead acquisitions (i.e., COMPUSTAT ACQ*-1) multiplied by 100 and deflated by current-year total assets

Capex One-year-ahead capital expenditure (i.e., COMPUSTAT CAPX) multiplied by 100 and deflated by current-year total assets 
$R \& D$

Overinvesting

(Underinivesting)

HighPerfPay

(LowPerfPay)

AmpleCash

ShortCash

HighGrowth

Institutions

Analysts

G-Score

G-Dummy

AccrualQuality

SalesGrowth

LogAsset
One-year-ahead research and development expenditure (i.e., the higher of R\&D expenditure and zero) multiplied by 100 and deflated by current-year total assets

An indicator variable for overinvesting (underinvesting). We estimate unexpected investment as the residual of the full-sample regression of one-yearahead total investment deflated by current total assets on current-year sales growth rate and Tobin's Q (i.e., the ratio of the market value of total assets to the book value of total assets) with industry- and year- fixed effects controlled. The industry-fixed effect is based on Fama and French's (1997) 48 industry classification. Overinvesting is equal to 1 for a group of firm-year observations in the top 25 percentile of the level of unexplained investment and 0 for a group of firm-year observations between the top and bottom 25 percentiles.

Underinvesting is equal to 1 for a group of firm-year observations in the bottom 25 percentile of the level of unexplained investment and 0 for a group of firmyear observations between the top and bottom 25 percentiles. Overinvesting and Underinvesting are also measured for acquisition, capital expenditures, and R\&D expenditures, respectively.

An indicator variable for firms with relatively high (low) ratio of performancebased pay to total pay. We measure the average ratio of CEO annual non-salary to CEO annual total pay (i.e., (tdc1 - salary)/tdc1) during three years immediately after the adoption year. We then classify a firm as a HighPerfPay (LowPerfPay) firm if its average ratio is higher (lower) than the sample median ratio.

An indicator for ample cash available for investment. We measure the average of the rank of cash and cash equivalents deflated by total assets and the rank of $-1 \times$ leverage among all Compustat firms with available data in a given year (following Biddle et al. 2009). We then classify as AmpleCash (Normal- or Short-Cash) firms a group of firms with top $20 \%$ (bottom $80 \%$ ) of this average rank during three years immediately before the adoption year.

An indicator for short cash available for investment. We classify as ShortCash (Normal- or Ample-Cash) a group of firms with bottom 25\% (higher 75\%) of this average rank during three years immediately before the adoption year.

An indicator variable for firms with relatively higher (lower) growth potential. We measure the average market-to-book ratio by each firm for the pre-adoption period ( $T-3$ to $T-1$ ). We then classify as HighGrowth (LowGrowth) firms whose average market-to-book ratios are higher (lower) than the total sample median.

The percentage of firm shares held by institutional investors

The number of analysts following the firm as provided by $\mathrm{I} / \mathrm{B} / \mathrm{E} / \mathrm{S}$

The measure of anti-takeover projection created by Gompers, Ishii, and Metrick (2003), multiplied by minus one

An indicator variable for firm-year observations with missing values of G-Score

The standard deviation of the firm-level residuals of working capital accruals from the Dechow and Dichev (2002) model during the years $t-5$ to $t-1$ and multiplied by minus one

The percentage change in sales from year $t-1$ to $t$

The log of total assets 
Mkt-to-Book

StdCFO

StdSale

StdInvestment

Z-Score

Tangibility

K-structure

Ind-K-Structure

Slack

CFOsale

Dividend

OperatingCycle

Losses

Age
The ratio of the market value of total assets to the book value of total assets

Standard deviation of cash flows from operating activities by average total assets from years $t-5$ to $t-1$

Standard deviation of sales deflated by average total assets from years $t-5$ to $t-1$

Standard deviation of capital investment from years $t-5$ to $t-1$

A proxy for bankruptcy risk based on the Altman (1968) Z-Score formula

The ratio of property, plant, and equipment to total assets

Capital structure measured as the book value of long-term debt/(the book value of long-term debt + the market value of equity)

Industry capital structure measured as the average of K-structure for all Compustat firms in the same SIC 3-digit industry given a year

The ratio of cash and cash equivalents to total assets

The ratio of $\mathrm{CFO}$ to sales

An indicator variable that takes the value of 1 if the firm paid a common or preferred dividend, and 0 otherwise

The log of receivables to sales plus inventory to cost of goods sold times 360

An indicator variable that takes the value of 1 if net income before extraordinary items is negative, and 0 otherwise.

The number of years that have been passed since the firm appears in CRSP 